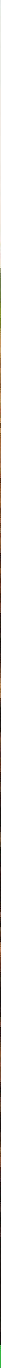

\title{
Klassenindelingen voor de fosfaattoestand van de bodem, ten behoeve van de afleiding van fosfaatgebruiksnormen
}

O. Oenema, J.P. Mol-Dijkstra, J.C. Voogd, P.A.I. Ehlert en G.L. Velthof

A LTERRA

WAEENINGENUR 



\section{Klassenindelingen voor de fosfaattoestand van de bodem, ten behoeve van de afleiding van fosfaatgebruiksnormen}

O. Oenema, J.P. Mol-Dijkstra, J.C. Voogd, P.A.I. Ehlert en G.L. Velthof 
Oenema, O., J.P. Mol-Dijkstra, J.C. Voogd, P.A.I. Ehlert en G.L. Velthof, 2016. Klassenindelingen voor de fosfaattoestand van de bodem, ten behoeve van de afleiding van fosfaatgebruiksnormen.

Wageningen, Alterra Wageningen UR (University \& Research centre), Alterra-rapport 2743. 40 blz.; 8 fig.; 28 tab.; 13 ref.

In 2006 is het stelsel van gebruiksnormen voor stikstof en fosfaat ingevoerd in de Nederlandse landbouw om de uit- en afspoeling van stikstof en fosfaat vanuit de landbouw naar grondwater en oppervlaktewater te verminderen. In 2010 zijn de gebruiksnormen voor fosfaat gedifferentieerd naar de fosfaattoestand van de bodem. Daarbij worden vier klassen voor de fosfaattoestand van de bodem onderscheiden, namelijk arm, laag, neutraal en hoog. De grenzen tussen de klassen worden bepaald via een bepaling van het Pw-getal (voor bouwland) en het P-AL-getal (voor grasland).

In 2015 heeft de Commissie Deskundigen Meststoffenwet (CDM) voorgesteld om de fosfaattoestand te bepalen op basis van een gecombineerde indicator, namelijk $\mathrm{P}-\mathrm{CaCl} 2$ en het $\mathrm{P}$-AL-getal, omdat een gecombineerde indicator in theorie een betere voorspelling geeft van de fosfaattoestand, en de gecombineerde indicator reeds in de praktijk en voor de bemestingsadviezen van grasland en maisland wordt toegepast. Ook speelt een rol dat het $\mathrm{Pw}$-getal door verschillende analyselaboratoria niet meer wordt bepaald.

In onderhavig rapport worden voor de gecombineerde indicator klassengrenzen afgeleid voor de fosfaattoestand van de bodem. Daarbij is gebruikgemaakt van een grote database (ruim 55.000 monsters) en van statistische analyses om een klassenindeling gebaseerd op het Pw-getal voor bouwland en op het P-AL-getal voor grasland om te rekenen naar een klassenindeling voor de gecombineerde indicator $\mathrm{P}-\mathrm{CaCl} 2$ en het $\mathrm{P}$-AL-getal. Verschillende varianten zijn voorgesteld. Effecten van de varianten op fosfaatplaatsingsruimte zijn verkend.

Trefwoorden: fosfaattoestand, bouwland, grasland, fosfaatgebruiksnormen, intensiteit-capaciteit

Dit rapport is gratis te downloaden van http://dx.doi.org/10.18174/390048 of op www.wageningenUR.nl/alterra (ga naar 'Alterra-rapporten' in de grijze balk onderaan). Alterra Wageningen UR verstrekt geen gedrukte exemplaren van rapporten.

2016 Alterra (instituut binnen de rechtspersoon Stichting Dienst Landbouwkundig Onderzoek), Postbus 47, 6700 AA Wageningen, T 03174807 00, E info.alterra@wur.nl, www.wageningenUR.nl/alterra. Alterra is onderdeel van Wageningen UR (University \& Research centre).

- Overname, verveelvoudiging of openbaarmaking van deze uitgave is toegestaan mits met duidelijke bronvermelding.

- Overname, verveelvoudiging of openbaarmaking is niet toegestaan voor commerciële doeleinden en/of geldelijk gewin.

- Overname, verveelvoudiging of openbaarmaking is niet toegestaan voor die gedeelten van deze uitgave waarvan duidelijk is dat de auteursrechten liggen bij derden en/of zijn voorbehouden.

Alterra aanvaardt geen aansprakelijkheid voor eventuele schade voortvloeiend uit het gebruik van de resultaten van dit onderzoek of de toepassing van de adviezen. 


\section{Inhoud}

$\begin{array}{ll}\text { Samenvatting } & 5\end{array}$

1

Inleiding

3.1 Klassenindeling voor een gecombineerde indicator-set met P-AL-getal en $\mathrm{P}-\mathrm{CaCl}_{2}$

3.2 Implicaties van voorgestelde klassengrenzen voor de fosfaatgebruiksruimte 16

3.2.1 Beschikbare gegevens

3.2.2 Berekeningswijze fosfaatgebruiksruimte 18

3.2.3 Berekende fosfaatgebruiksruimte

3.3 Alternatieve klassenindeling voor de gecombineerde indicator-set met $\mathrm{P}$-AL-getal en $\mathrm{P}-\mathrm{CaCl}_{2}$

3.4 Voorstellen met een $5 \times 5$ matrix van klassenindeling voor de gecombineerde indicator-set met P-AL-getal en $\mathrm{P}-\mathrm{CaCl}_{2}$

3.5 Klassenindeling voor een gecombineerde indicator-set met $\mathrm{P}-\mathrm{CaCl}_{2}$, oxalaatextraheerbaar fosfaat (P-ox) en fosfaatverzadigingsgraad (FVG)

4.1 Implicaties voorgestelde klassengrenzen voor gewasopbrengsten $\quad 31$

4.2 Implicaties voorgestelde klassengrenzen voor fosfaatverliezen 32

4.3 Implicaties voorgestelde klassengrenzen voor fosfaatgebruiksruimte 32

4.4 Conclusies 33

$\begin{array}{ll}\text { Literatuur } & 34\end{array}$

Bijlage 1 Afleiding statistische relaties tussen $\mathrm{P}-\mathrm{CaCl}_{2}$ en $\mathrm{Pw}-\mathrm{getal} \quad 35$

Bijlage 2 Arealen per landgebruikstype en per P-klasse bestand RV02015 38 



\section{Samenvatting}

In 2006 is het stelsel van gebruiksnormen voor stikstof en fosfaat ingevoerd in de Nederlandse landbouw, om de uit- en afspoeling van stikstof en fosfaat vanuit de landbouw naar grondwater en oppervlaktewater te verminderen. In 2010 zijn de gebruiksnormen voor fosfaat gedifferentieerd naar de fosfaattoestand van de bodem. Daarbij worden vier klassen voor de fosfaattoestand van de bodem onderscheiden, namelijk arm, laag, neutraal en hoog. De grenzen tussen de klassen worden bepaald via een bepaling van het Pw-getal (voor bouwland) en het P-AL-getal (voor grasland).

In 2004 is een gecombineerde indicator voor bepaling van de fosfaattoestand in de bemestingspraktijk geïntroduceerd. Sindsdien wordt de fosfaattoestand in toenemende mate bepaald door een combinatie van $\mathrm{P}-\mathrm{CaCl}_{2}$ en het P-AL-getal (en wordt het Pw-getal steeds minder gemeten). Voorjaar 2015 heeft de Commissie Deskundigen Meststoffenwet voorgesteld aan het ministerie van EZ om de fosfaatgebruiksnormen ook te baseren op een fosfaattoestand die bepaald is met de gecombineerde indicator $\mathrm{P}-\mathrm{CaCl}_{2}$ en het $\mathrm{P}$-AL-getal. Klassengrenzen werden echter niet voorgesteld.

In dit rapport worden voorstellen voor klassengrenzen van het $\mathrm{P}-\mathrm{CaCl}_{2}$ en het $\mathrm{P}-\mathrm{AL}$-getal gedaan, ten behoeve van de afleiding van de fosfaattoestand-afhankelijke fosfaatgebruiksnormen. De voorstellen zijn gebaseerd op een dataset van ruim 55.000 grondmonsteranalyses van Eurofins Agro. Per grondmonster is een reeks van kenmerken bepaald, inclusief Pw-getal, P-AL-getal, P-CaCl , P-totaal, oxalaat-extraheerbaar $\mathrm{P}$, lutum, $\mathrm{pH}$ en organische stof. Dit databestand is ook vergeleken met een databestand van RVO, dat de recentste gegevens over de fosfaattoestand (op basis van Pw-getal en P-AL-getal) en areaalgrootte van de percelen bouwland en grasland in Nederland bevat.

Voor de gecombineerde indicator zijn klassengrenzen voor $\mathrm{P}-\mathrm{CaCl}_{2}$ afgeleid van de klassengrenzen voor het Pw-getal voor bouwland, via lineaire regressie. Dit impliceert dat de klassengrenzen voor de gecombineerde indicator een direct verband houden met de oorspronkelijk klassengrenzen voor bouwland en grasland, met dit verschil dat de oorspronkelijke klassengrenzen voor het P-AL-getal nu ook van toepassing worden geacht voor bouwland, en dat de oorspronkelijke klassengrenzen voor het $\mathrm{Pw}$-getal (na omrekening naar $\mathrm{P}-\mathrm{CaCl}_{2}$ ) nu ook van toepassing worden geacht voor grasland. In Tabel S1 is dat schema voor alle landbouwgronden weergegeven. In de hoofdtekst is de tabel ook uitgesplitst naar bouwland en grasland.

\section{Tabel S1}

Voorstel voor klassengrenzen van de fosfaattoestand van bouwland en grasland met een gecombineerde indicator ( $P-\mathrm{CaCl}_{2}$-SFA als intensiteitsindicator en het P-AL-getal als capaciteitsindicator). Voor iedere gecombineerde klasse is het percentage van het totaal aantal monsters op landbouwgrond (grasland + bouwland) weergegeven, op basis van data Eurofins. Kleuren geven de waardering van de fosfaattoestand weer: groen=arm, lichtgroen=laag, geel=neutraal, oranje=hoog.

\begin{tabular}{|c|c|c|c|c|}
\hline \multirow{2}{*}{$\begin{array}{l}\mathrm{P}-\mathrm{CaCl}_{2}-\mathrm{SFA} \text {, } \\
\text { mg P kg } \\
\text { gemiddelde ( } \pm 2 \times \text { standaardafwijking) }\end{array}$} & \multicolumn{4}{|c|}{$\begin{array}{l}\text { Percentage monsters per fosfaattoestandsklasse, uitgedrukt } \\
\text { in P-AL-getal, } \mathrm{mg} \mathrm{P}_{2} \mathrm{O}_{5}(100 \mathrm{~g})^{-1}\end{array}$} \\
\hline & $<16$ & $16-27$ & $27-50$ & $>50$ \\
\hline$<0,8(0,4-1,6)$ & 2 & 6 & 7 & 1 \\
\hline $0,8-1,4(0,4-3,0)$ & 0 & 3 & 13 & 5 \\
\hline $1,4-3,1(0,7-6,6)$ & 0 & 2 & 17 & 15 \\
\hline$>3,1(1,5-6,6)$ & 0 & 1 & 7 & 21 \\
\hline
\end{tabular}

Tabel S1 geeft een 4x4 matrix weer. Er zijn ook voorstellen uitgewerkt met een 5x5 matrix, waarbij ook een waarderingsklasse 'zeer hoog' is onderscheiden. Per voorstel is steeds het aantal monsters per waarderingsklasse berekend en voor verschillende voorstellen is ook de totale 
fosfaatgebruiksruimte in Nederland berekend. De totale fosfaatgebruiksruimte is de gesommeerde fosfaatgebruiksnorm per perceel per landgebruik in Nederland.

Bij het uitwerken van een 5x5 matrix spelen twee overwegingen een rol: (i) vanuit bemestingsoogpunt is het van belang in de waarderingsklassen arm en laag meer onderscheid aan te brengen, omdat in die klassen een duidelijke gewasreactie op de fosfaattoestand optreedt. Echter, in de waarderingsklassen arm en laag komen relatief weinig monsters voor (Tabel S1). (ii) Vanuit milieukundig oogpunt is het van belang om in de waarderingsklassen neutraal en hoog meer onderscheid in gebruiksnormen aan te brengen, omdat percelen met een hoge fosfaattoestand geen bemesting nodig hebben en een relatief groot risico geven op fosfaatverliezen door uitspoeling. Met andere woorden, er zijn argumenten om het begintraject, het eindtraject en het gehele traject (als tussenvorm) 'uit te rekken'. Tabel S2 geeft een voorbeeld van een voorstel waarin het gehele traject is uitgerekt/aangepast.

\section{Tabel S2}

Voorstel voor een indeling met 5 × 5 klassen voor de waardering van de fosfaattoestand van landbouwgrond (grasland en bouwland), waarbij waarden voor alle klassen zijn 'genormaliseerd' op hele getallen (bij P-CaCl $2-S F A$ ) en eenheden van 10 (P-AL-getal).

\begin{tabular}{|c|c|c|c|c|c|}
\hline \multirow{2}{*}{$\begin{array}{l}\text { P-CaCl2-SFA, } \\
\text { mg P kg-1 } \\
\text { gemiddelde }\end{array}$} & \multicolumn{5}{|c|}{$\begin{array}{l}\text { Percentage monsters per fosfaattoestandsklasse, uitgedrukt in P-AL-getal, mg } \\
\qquad \mathrm{P}_{2} \mathrm{O}_{5}(100 \mathrm{~g})^{-1}\end{array}$} \\
\hline & $<20$ & $20-30$ & $30-40$ & $40-60$ & $>60$ \\
\hline $1,0-2,0$ & arm & laag & neutraal & neutraal & hoog \\
\hline $2,0-3,0$ & laag & neutraal & neutraal & hoog & hoog \\
\hline$>4,0$ & neutraal & hoog & hoog & zeer hoog & zeer hoog \\
\hline
\end{tabular}

In de literatuur zijn ook voorstellen gedaan om de fosfaattoestand te beschrijven op basis van $\mathrm{P}-\mathrm{CaCl}_{2}$ en de zogenoemde buffercapaciteit, de verhouding tussen het P-AL-getal en $\mathrm{P}-\mathrm{CaCl}_{2}$. In onderhavige studie is daar niet voor gekozen, omdat de voorkeur wordt gegeven aan een onafhankelijke combinatie van twee indicatoren. Bij de keuze voor een combinatie van $\mathrm{P}-\mathrm{CaCl}_{2}$ en buffercapaciteit zijn de twee indicatoren met elkaar verstrengeld. Overigens kan de buffercapaciteit ook uit onafhankelijke indicatoren $\mathrm{P}-\mathrm{CaCl}_{2}$ en het P-AL-getal in de Tabellen S1 en S2 worden afgeleid door denkbeeldige lijnen (iso-lijnen) te trekken vanuit de oorsprong (linkerbovenhoek) naar (rechts) beneden. De waarderingsklassen voor de fosfaattoestand in de rechterbovenhoek hebben een hoge buffercapaciteit en die in de linkeronderhoek een kleine.

Er zijn ook voorstellen gemaakt voor klassengrenzen voor de gecombineerde indicator $\mathrm{P}-\mathrm{CaCl}_{2}$ en oxalaat-extraheerbaar fosfaat ( $\mathrm{P}-\mathrm{ox}$ ), en voor de combinatie $\mathrm{P}-\mathrm{CaCl}_{2}$ en fosfaatverzadigingsgraad (FVG), waarbij zowel P-ox als FVG zijn afgeleid uit het P-AL-getal via lineaire regressie. De rationale om te kiezen voor P-ox en FVG is dat dit indicatoren zijn voor het risico van fosfaatverliezen door uitspoeling, terwijl P-ox en FVG ook redelijk goede indicatoren zijn voor (de gewasreactie op) de fosfaattoestand.

De keuze voor een bepaalde gecombineerde indicator voor de fosfaattoestand van landbouwgronden zal moeten worden gemaakt door het ministerie van Economische Zaken, in overleg met de sector. De vraag is daarbij of aparte waarderingsklassen voor de fosfaattoestand van bouwland en grasland worden onderscheiden of een voor alle landbouwgronden samen. Bij een gecombineerde indicator zijn er vanuit bemestingsoogmerk weinig argumenten om een aparte waardering te onderscheiden, al blijkt uit onderhavige studie dat de overgang naar een gecombineerde indicator een groter effect heeft op de fosfaatgebruiksruimte van bouwland dan op die van grasland in Nederland. Een andere vraag heeft betrekking op het aantal te onderscheiden waarderingsklassen en de grenzen tussen die klassen. De antwoorden op deze vragen bepalen de totale fosfaatgebruiksruimte. De verschillen in fosfaatgebruiksruimte door verschillen in aantal klassen en ligging van de grenzen is overigens niet groot. Dat heeft te maken met (i) de vele percelen met hoge of neutrale fosfaattoestand (meer dan 
$75 \%$ ), en (ii) de relatief geringe verschillen in huidige fosfaatgebruiksnorm als functie van de fosfaattoestand (tussen laag en neutraal $10 \mathrm{~kg} \mathrm{P}_{2} \mathrm{O}_{5} \mathrm{ha}^{-1}$ jaar $^{-1}$ voor grasland en $15 \mathrm{~kg}$ voor bouwland, en tussen neutraal en hoog $10 \mathrm{~kg} \mathrm{P}_{2} \mathrm{O}_{5} \mathrm{ha}^{-1} \mathrm{jaar}^{-1}$ ). Daarenboven is van veel percelen de fosfaattoestand niet bepaald, waardoor automatisch de laagste fosfaatgebruiksnorm van toepassing is.

Een stelsel van fosfaatgebruiksnormen als functie van de fosfaattoestand, bepaald via een gecombineerde indicator (intensiteits- en capaciteitsindicatoren), biedt de mogelijkheid om een economisch rendabele gewasproductie te combineren met een hoge fosfaatbenutting en beperking van fosfaatverliezen naar de ondergrond en oppervlaktewater. Dit vereist finetuning en monitoring. 


\section{$1 \quad$ Inleiding}

In 2006 is het stelsel van gebruiksnormen voor stikstof en fosfaat ingevoerd in de Nederlandse landbouw, om de uit- en afspoeling van stikstof en fosfaat vanuit de landbouw naar grondwater en oppervlaktewater te verminderen en om daarmee te voldoen aan de verplichtingen van de Nitraatrichtlijn en de Kaderrichtlijn Water van de Europese Unie (Rijksoverheid, 2004). In 2010 zijn de gebruiksnormen voor fosfaat gedifferentieerd naar de fosfaattoestand van de bodem (Rijksoverheid, 2009).

In het stelsel van gedifferentieerde fosfaatgebruiksnormen worden vier klassen voor de fosfaattoestand van de bodem onderscheiden, namelijk arm, laag, neutraal en hoog, en een gefaseerde verlaging van de gebruiksnormen (Tabel 1; Rijksoverheid, 2014). De grenzen tussen de klassen arm, laag, neutraal en hoog worden bepaald via een meting van het Pw-getal (voor bouwland) en het P-AL-getal (voor grasland). Het uiteindelijke doel van de differentiatie van fosfaatgebruiksnormen is om op termijn voor alle landbouwgronden een fosfaattoestand te realiseren waarbij gemiddeld evenwichtsbemesting wordt gerealiseerd.

Tabel 1

Fosfaatgebruiksnormen (in $\mathrm{kg} \mathrm{P}_{2} \mathrm{O}_{5}$ per ha per jaar) voor bouwland en grasland, als functie van de fosfaattoestand van de bodem volgens het vierde en vijfde Actie Programma van de EU-Nitraatrichtlijn (Rijksoverheid 2009, 2014).

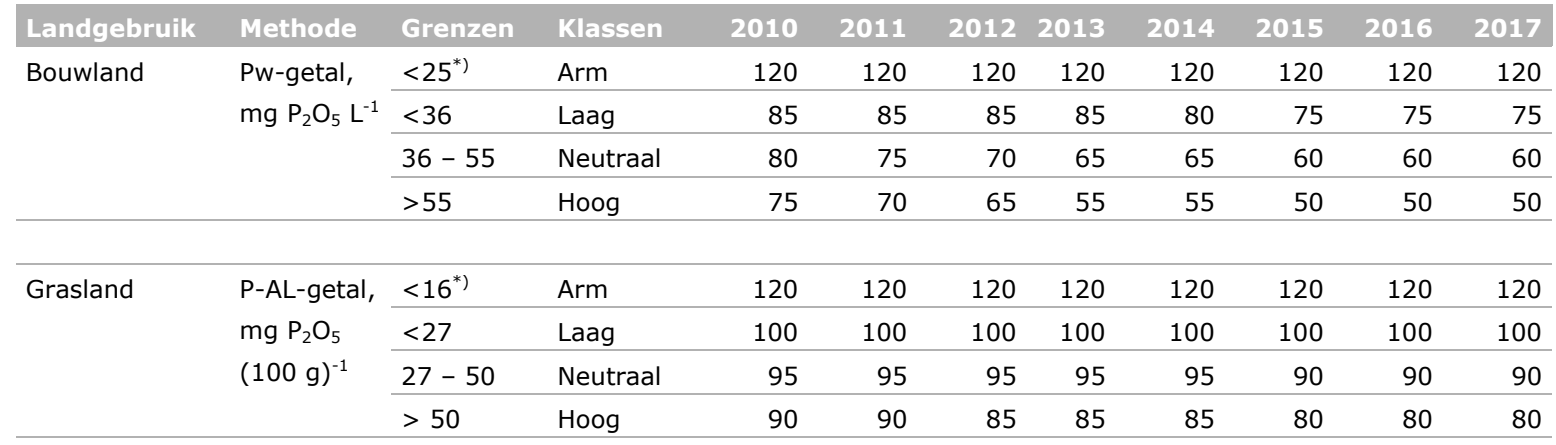

*) Fosfaatarme en fosfaatfixerende gronden, bemonsterd via een specifiek bemonsteringsprotocol.

Er zijn verschillende analysemethoden voor de bepaling van de fosfaattoestand van de bodem ten behoeve van bemestingsadvisering (Ehlert et al., 2014). In Nederland werden tot voor kort vooral het Pw-getal (vooral bij bouwland en groenteteelt in de volle grond) en het P-AL-getal (vooral bij grasland) toegepast, en dat is de reden dat deze methoden in 2010 werden voorgeschreven voor bepaling van de fosfaattoestand ten behoeve van de fosfaattoestand-afhankelijke gebruiksnormen (Tabel 1).

Wetenschappelijke onderzoeksinstellingen en analyselaboratoria ontwikkelen geregeld nieuwe en/of verbeterde analysemethoden voor de bepaling van de fosfaattoestand. Eurofins Agro (het vroegere BLGG AgroXpertus) in Wageningen heeft in 2004 een procedure op de markt gebracht waarbij de fosfaattoestand van de bodem wordt bepaald met een combinatie van analysemethoden, namelijk een methode die de direct beschikbare fractie bepaalt (intensiteitsindicator) en een methode die de voorraad

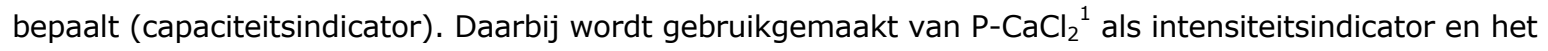

\footnotetext{
${ }^{1} \mathrm{P}_{-\mathrm{CaCl}_{2}}: 1: 10(\mathrm{w} / \mathrm{v})$ extractie met $0.01 \mathrm{M} \mathrm{CaCl}_{2}$. Eurofins Agro noemt deze parameter PPAE (Phosphorus Plant Available Elements).
} 
P-AL-getal ${ }^{2}$ als capaciteitsindicator (zie ook box 1 ). Dit concept is door de Commissie Bemesting Grasland en Voedergewassen inmiddels verwerkt in de bemestingsadviezen van grasland en maisland.

\section{Box 1. Ontwikkelingen in grondonderzoek}

Een belangrijke reden voor de veranderingen in de bepaling van de fosfaattoestand in Nederland is het feit dat de bepaling van het Pw-getal laboratorium-technisch lastig is. De bepaling is omslachtig, vergt daardoor relatief veel tijd en is daardoor relatief duur. De bepaling is bovendien gevoelig voor monstervoorbehandeling en laboratoriumcondities, waardoor er systematische verschillen tussen laboratoria kunnen ontstaan en de reproduceerbaarheid van de bepaling relatief gering is. Tegelijkertijd is er bij analyselaboratoria een noodzaak om de diagnostische waarde van het grondonderzoek te verbeteren (boeren willen meer weten) en om de kosten van het grondonderzoek te verlagen (boeren willen minder betalen). Bovendien speelt internationalisering een rol; laboratoria werken in toenemende mate in meerdere landen, waardoor de behoefte aan uniformering van analysemethoden toeneemt. Laboratoria zijn daarom op zoek naar multinutriënten-extractiemethoden die in meerdere landen toegepast kunnen worden, d.w.z. een extractiemethode waarmee de beschikbaarheid van stikstof, fosfaat, kalium en andere essentiële nutriënten in de bodem gelijktijdig bepaald kan worden. De extractie met $0.01 \mathrm{M} \mathrm{CaCl}_{2}$ is een mogelijke multinutriënten-extractiemethode (Van Erp, 2002). Deze methode heeft in ons omringende landen de daar gangbare methoden echter nog niet vervangen. Veel landen hebben hun eigen grondonderzoekmethoden (Jordan-Meille et al., 2012), zo ook Nederland (de Pwbepaling is destijds alleen in Nederland ingevoerd in de bemestingspraktijk).

Vanwege de voornoemde laboratorium-technische problemen wordt het Pw-getal door Eurofins Agro voor de praktijk afgeleid uit andere bepalingen van grondonderzoek (berekend Pw-getal verkregen door regressieanalyse), en wordt in toenemende mate een gecombineerde indicator gebruikt voor de vaststelling van de fosfaattoestand van de bodem, namelijk het $\mathrm{P}-\mathrm{CaCl}_{2}$ en het $\mathrm{P}$-AL-getal. Het idee van een gecombineerde indicator als superieure indicator voor de bepaling van het nutriënten-leverend vermogen van de bodem is al minstens vijftig jaar oud, maar vanwege kostenoverwegingen vrijwel niet in de praktijk ingevoerd. Met een multinutriënten-extractiemethode en de introductie van snelle analysetechnieken zoals Near Infra-Red Spectroscopy (NIRS) en Inductively Coupled Plasma Mass Spectrometry (ICP-MS), wordt een gecombineerde indicator voor het nutriënten-leverend vermogen van de bodem veel eerder toepasbaar.

In kortdurende, intensieve teelten is er een voorkeur om een afgeleide van de direct beschikbare fractie van het nutriënten-leverend vermogen van de bodem te bepalen, en daarom is daar in het verleden veelal gekozen voor intensiteitsindicatoren. In meer extensieve en meerjarige teelten (inclusief grasland) is er een voorkeur om de capaciteit van het nutriënten-leverend vermogen van de bodem te bepalen (de bodemvoorraad via capaciteitsindicatoren). In beide gevallen is er echter ook behoefte aan kennis over respectievelijk de nutriëntenvoorraad in de bodem (capaciteit) en de direct beschikbare hoeveelheden nutriënten. Dit zijn de belangrijkste redenen voor de interesse in gecombineerde indicatoren in het grondonderzoek.

Het ministerie van Economische Zaken heeft in 2013 aan de Commissie Deskundigen Meststoffenwet (CDM) advies gevraagd over de geschiktste analysemethoden voor de bepaling van de fosfaattoestand ten behoeve van de fosfaattoestand-afhankelijke gebruiksnormen. In het CDM-advies zijn vijf opties uitgewerkt (Commissie Deskundigen Meststoffenwet, 2015):

Optie 1: Geen wijziging van indicatoren

Optie 2: Uniforme, gecombineerde indicator, op basis van $\mathrm{P}-\mathrm{CaCl}_{2}$ en $\mathrm{P}-\mathrm{AL}$-getal;

Optie 3: Uniforme, gecombineerde indicatoren met P-AL-getal vervangen door P-ox of FVG

Optie 4: Een vereenvoudigd stelsel met een enkelvoudige indicator (P-AL of Pox)

Optie 5: De fosfaatbalans als basis voor de afleiding van fosfaatgebruiksnormen

Elke optie heeft voor- en nadelen, afhankelijk ook van de beleidsuitgangspunten. In het CDM-advies wordt een lichte voorkeur uitgesproken voor optie 2, omdat deze optie aansluit bij de huidige systematiek van de fosfaatbemestingsadvisering (vanaf 2004 wordt in de praktijk in toenemende mate

2 P-Al-getal: $1: 20(\mathrm{w} / \mathrm{v})$ extractie met $0.4 \mathrm{~N}$ azijnzuur en $0.1 \mathrm{~N}$ ammoniumacetaat pH 3.75. 
gebruikgemaakt van de gecombineerde indicator, op basis van het $\mathrm{P}-\mathrm{CaCl}_{2}$ en $\mathrm{P}$-AL-getal). In het CDM-advies worden echter geen waarden (getallen) gegeven voor de klassenindelingen voor $\mathrm{P}-\mathrm{CaCl}_{2}$ (Tabel 2), omdat de beleidsuitgangspunten en data voor de afleiding van klassengrenzen op dat moment ontbraken.

\section{Tabel 2}

Voorstel voor een uniforme beoordeling van de fosfaattoestand van grasland en bouwland met een gecombineerde indicator ( $P$ - $\mathrm{CaCl}_{2}$-SFA als intensiteitsindicator en het $P$-AL-getal als capaciteitsindicator). De aanduidingen arm, laag, neutraal en hoog geven aan welke fosfaatgebruiksnormen van toepassing zijn (Commissie Deskundigen Meststoffenwet, 2015).

\begin{tabular}{|c|c|c|c|c|}
\hline \multirow[t]{2}{*}{$\begin{array}{l}\mathrm{P}-\mathrm{CaCl}_{2}-\mathrm{SFA} \text {, } \\
\mathrm{mg} \mathrm{P} \mathrm{kg}\end{array}$} & \multicolumn{4}{|c|}{$\begin{array}{l}\text { Waardering fosfaattoestand van bouwland en grasland per klasse, } \\
\qquad \text { P-AL-getal, } \mathrm{mg} \mathrm{P}_{2} \mathrm{O}_{5}(100 \mathrm{~g})^{-1}\end{array}$} \\
\hline & $<16$ & $<27$ & $27-50$ & $>50$ \\
\hline B & arm & laag & neutraal & neutraal \\
\hline C & laag & neutraal & neutraal & hoog \\
\hline
\end{tabular}

*Klassengrenzen dienen nog vastgesteld te worden.

In reactie op het voornoemde CDM-rapport (Commissie Deskundigen Meststoffenwet, 2015) heeft het ministerie van Economische Zaken een voorkeur voor optie 2 uitgesproken. Ook heeft het ministerie de beleidsuitgangspunten en -doelen voor de vaststelling van de klassengrenzen aangegeven. De klassengrenzen zouden zo vastgesteld moeten worden dat vastgehouden wordt aan het principe dat op de (langere) termijn alle landbouwgronden in principe in de range terechtkomen waarbij er een balans is tussen voldoende bodemvruchtbaarheid en bemesting om kwaliteit en kwantiteit van gewassen te waarborgen en milieuverliezen te beperken (klasse 'neutraal'). De klasse 'laag' moet die landbouwgronden omvatten waar daadwerkelijk sprake is van een tekort aan (beschikbaar) fosfaat voor het gewas. De klasse 'hoog' moet die gronden omvatten waar sprake is van een verhoogd risico op uitspoeling. Uitgangspunt moet ook zijn dat de landelijk fosfaatruimte niet significant verandert ten opzichte van de situatie in 2015.

In overleg met het ministerie van Economische Zaken heeft Eurofins Agro aan Alterra een grote dataset beschikbaar gesteld en gevraagd om voorstellen te doen voor mogelijke klassengrenzen, op basis van de beleidsuitgangspunten. De dataset bevat resultaten van de chemische analyse van ruim 55.000 grondmonsters uit Nederland. Alterra heeft deze dataset geanalyseerd en voorstellen gemaakt voor mogelijke klassengrenzen voor het stelsel van fosfaattoestand-afhankelijke gebruiksnormen.

Dit rapport beschrijft de dataset en de voorstellen voor mogelijke klassengrenzen voor het stelsel van fosfaattoestand-afhankelijke gebruiksnormen. Ten behoeve van de analyse van de dataset zijn de volgende onderzoeksvragen geformuleerd:

1. Wat zijn de statistische relaties tussen het $\mathrm{Pw}$-getal en $\mathrm{P}-\mathrm{CaCl}_{2}$ voor grasland en bouwland; wat zijn de standaardafwijkingen van de gemiddelde regressiecoëfficiënten?

2. Wat zijn mogelijke klassengrenzen voor de fosfaattoestand bij de fosfaattoestand-afhankelijke fosfaatgebruiksnormen, gegeven de afgeleide relaties tussen het $\mathrm{Pw}$-getal en $\mathrm{P}-\mathrm{CaCl}_{2}$ ?

3. Wat zijn de implicaties van de voorgestelde klassengrenzen voor de fosfaatgebruiksruimte op grasland en bouwland in Nederland? Wat zijn de implicaties van de voorgenomen klassengrenzen voor de fosfaatgebruiksruimte op grasland en bouwland op basis van de actueelste informatie over de fosfaattoestand van de bodem van RVO.nl?

4. Wat zijn de statistische relaties tussen P-ox en het P-AL-getal voor grasland en bouwland; wat zijn de standaardafwijkingen van de gemiddelde regressiecoëfficiënten en wat zijn mogelijke klassengrenzen voor de fosfaattoestand bij vervanging van P-AL-getal door P-ox?

5. Wat zijn de statistische relaties tussen de fosfaatverzadigingsgraad (FVG) en PAL voor grasland en bouwland; wat zijn de standaardafwijkingen van de gemiddelde regressiecoëfficiënten en wat zijn mogelijke klassengrenzen voor de fosfaattoestand bij vervanging van het P-AL-getal door FVG? 


\section{$2 \quad$ Beschrijving en analyse dataset}

Eurofins Agro analyseert jaarlijks honderdduizenden grondmonsters afkomstig van grasland en bouwland om bodemvruchtbaarheidsparameters te bepalen, op verzoek van boeren, landeigenaren en/of onderzoeksinstellingen. Afhankelijk van het verzoek worden er verschillende bodemvruchtbaarheidsparameters bepaald.

Onderhavige database bevat analyseresultaten van 55.339 grondmonsters die zijn geselecteerd uit een database met resultaten van de voornoemde routinematige bemonstering en analyse van de bovengrond van bouwland en grasland in Nederland. De selectie vond plaats op basis van bodemvruchtbaarheidsparameters; gezocht is naar monsters waarvan een groot aantal fosfaatgerelateerde parameters zijn bepaald. Van de geselecteerde monsters zijn bekend: de locatie (postcode), perceelnaam, landgebruik, grondsoort, diepte van de monstername, P-totaal, zuur ammoniumoxalaat-extraheerbaar fosfaat (P-ox), zuur ammoniumoxalaat-extraheerbaar aluminium (AL-ox), zuur ammoniumoxalaat-extraheerbaar ijzer (Fe-ox), fosfaatbindend vermogen (FBV), fosfaatverzadigingsgraad (FVG), P-AL-getal, $\mathrm{Pw}$-getal, $\mathrm{P}-\mathrm{CaCl}_{2}, \mathrm{pH}$, organische stofgehalte en lutumgehalte. De grondmonsters zijn afkomstig uit geheel Nederland (Figuur 1).

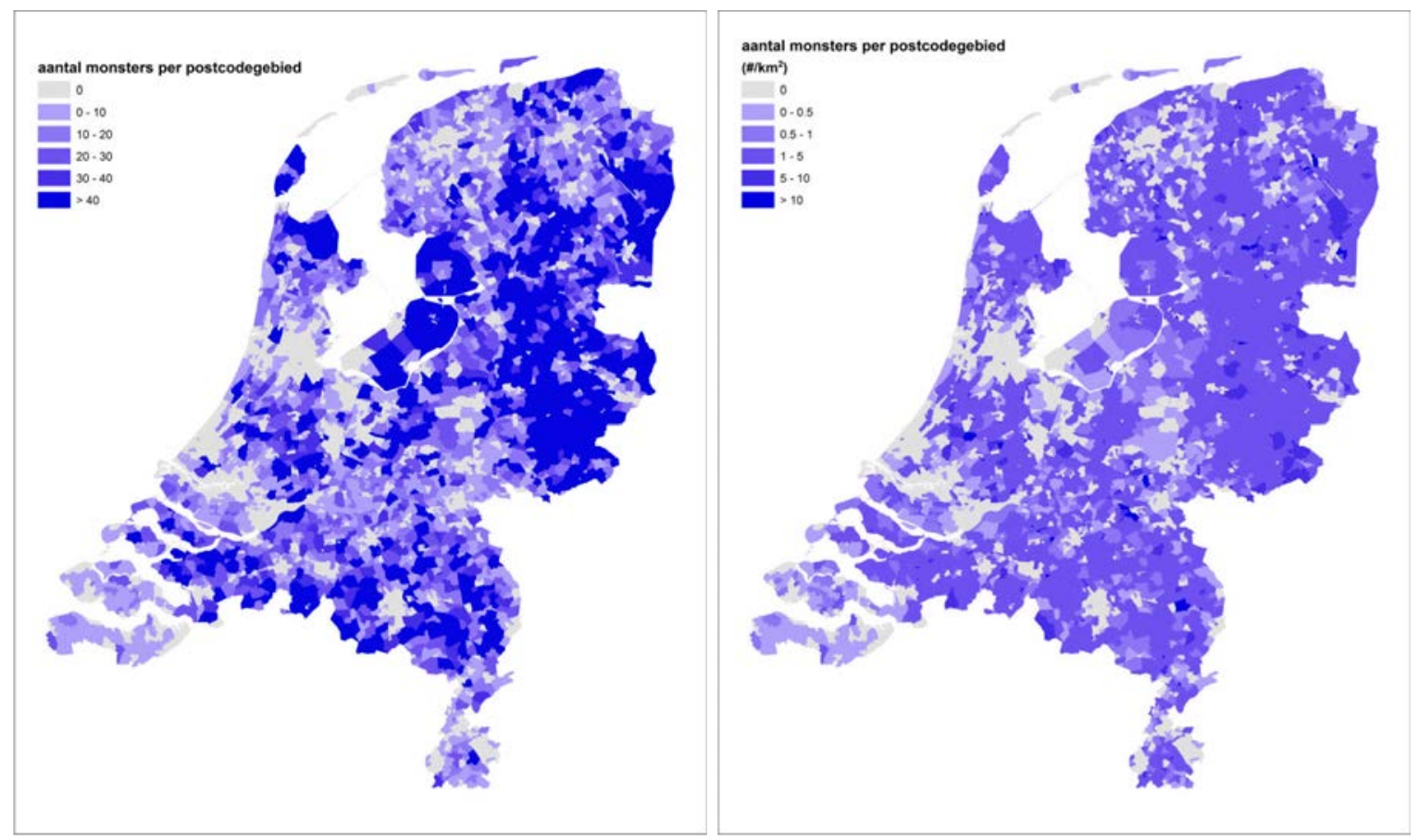

Figuur 1 Aantal monsters per postcodegebied (links) en aantal monsters per $\mathrm{km}^{2}$ landbouwgrond per postcodegebied (rechts).

Relatief veel monsters zijn afkomstig van zandgronden uit het oosten van het land (Figuur 1). Dat komt ook tot uiting in de frequentieverdelingen; circa driekwart van het aantal monsters heeft een lutumgehalte van minder dan 10\% (Figuur 2). Veel frequentieverdelingen zijn 'skewed' (scheefverdeeld) naar rechts, d.w.z. een beperkt aantal monsters heeft relatief hoge waarden. Dat geldt ook voor de fosfaattoestand, zowel het Pw-getal, het P-AL-getal, $\mathrm{P}-\mathrm{CaCl}_{2}$ en de fosfaatverzadigingsgraad (FVG) en het fosfaatbindend vermogen (FBV) zijn skewed naar rechts (maar niet extreem). Dit wordt frequent waargenomen in praktijksituaties (Reijneveld, 2013). 

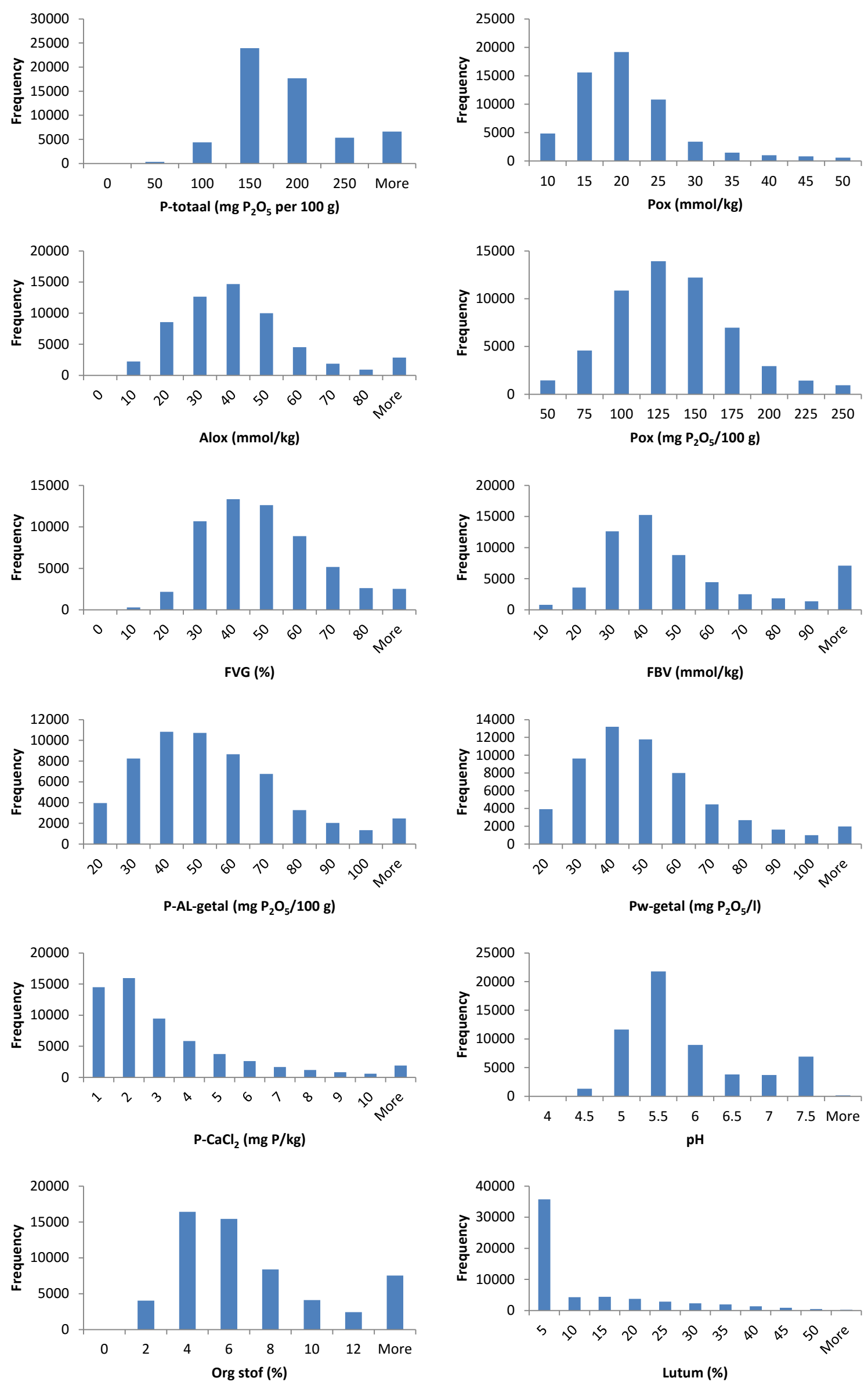

Figuur 2 Frequentiediagrammen voor variabelen in de Eurofins-database, met aantal monsters per klasse op de $y$-as. 


\section{Voorstellen voor klassenindelingen}

\subsection{Klassenindeling voor een gecombineerde indicator-set met P-AL-getal en $\mathrm{P}-\mathrm{CaCl}_{2}$}

De hier voorgestelde klassenindelingen voor een gecombineerde indicator voor de fosfaattoestand van de bodem, ten behoeve van de afleiding van fosfaatgebruiksnormen, zijn gebaseerd op bestaande analysegegevens en indirect ook op basis van het empirische bemestingsonderzoek dat in het verleden heeft plaatsgevonden. De bemestingsadviezen voor bouwland zijn meer dan vijftig jaar gebaseerd geweest op het Pw-getal en die voor grasland op het P-AL-getal, en voor beide adviezen zijn in het verleden vele honderden veldproeven uitgevoerd. De klassengrenzen voor het Pw-getal en het P-AL-getal in het huidige systeem van fosfaattoestand-afhankelijke fosfaatgebruiksnormen zijn gebaseerd op de bemestingsadviesbasis voor fosfaat, die gebaseerd is op empirisch onderzoek, op honderden veldproeven. Deze informatie wordt in de voorstellen die hieronder zijn weergegeven wederom benut.

Het Pw-getal ${ }^{3}$ is een intensiteitsparameter, evenals $\mathrm{P}-\mathrm{CaCl}_{2}$ (Ehlert et al., 2014). Het Pw-getal en $\mathrm{P}-\mathrm{CaCl}_{2}$ zijn bovendien sterk met elkaar gecorreleerd (Ehlert et al., 2014), al geldt dit minder voor grondmonsters met een lage fosfaattoestand (Ehlert et al., 2007). Voor de afleiding van klassengrenzen voor de gecombineerde indicator met het $\mathrm{P}-\mathrm{AL}$-getal en $\mathrm{P}-\mathrm{CaCl}_{2}$ is er in onderhavige studie voor gekozen om $\mathrm{P}-\mathrm{CaCl}_{2}$ af te leiden uit het $\mathrm{Pw}$-getal via regressieanalyse. Vervolgens zijn de huidige klassengrenzen voor het $\mathrm{Pw}$-getal omgerekend naar $\mathrm{P}-\mathrm{CaCl}_{2}$.

Uit gemaakte scatterplots blijkt dat $\mathrm{P}-\mathrm{CaCl}_{2}$ sterk gerelateerd is aan het $\mathrm{Pw}$-getal. Het lineaire verband $\left[\mathrm{P}-\mathrm{CaCl}_{2}=\mathrm{a}+\mathrm{b} * \mathrm{Pw}\right]$ verklaart $75 \%$ van de variantie bij bouwland en $82 \%$ bij grasland. Verschillende andere statistische modellen zijn getoetst, zowel lineaire, log-getransformeerde en exponentiële modellen. Alle modellen hadden een relatief hoge verklaarde variantie. Effecten van het lutumgehalte, $\mathrm{pH}$ en organische stofgehalte op de relatie tussen het $\mathrm{Pw}$-getal en $\mathrm{P}-\mathrm{CaCl}_{2}$ waren klein. Dit geeft aan dat het verband tussen $\mathrm{P}-\mathrm{CaCl}_{2}$ en het $\mathrm{Pw}$-getal slechts in beperkte mate wordt beïnvloed door $\mathrm{pH}$, lutumgehalte en organische stofgehalte. Daarom zijn deze variabelen niet meegenomen in de gedane voorstellen.

\section{Tabel 3}

Coëfficiënten en standaardafwijkingen van het exponentieel en log-getransformeerd model voor de relatie tussen $\mathrm{P}-\mathrm{CaCl}_{2}$ en $\mathrm{PW}$-getal per landgebruik.

\begin{tabular}{|c|c|c|c|c|c|c|c|c|}
\hline \multirow[t]{2}{*}{ Model } & \multirow[t]{2}{*}{ Landgebruik } & \multicolumn{3}{|c|}{ Coëfficiënten } & \multicolumn{3}{|c|}{ Standaardfout } & \multirow[t]{2}{*}{$\mathbf{R}^{2}$} \\
\hline & & a & b & D & a & b & D & \\
\hline \multirow{2}{*}{$\begin{array}{l}\mathrm{Ln}\left(\mathrm{P}-\mathrm{CaCl}_{2}\right)=\mathrm{a}+\mathrm{b} * \\
\mathrm{D}^{\wedge} \mathrm{PW}\end{array}$} & Akker- en tuinbouw & 3,00 & $-5,35$ & 0,98 & 0,019 & 0,016 & $<0,001$ & 81 \\
\hline & $\begin{array}{l}\text { Akker- en tuinbouw \& } \\
\text { grasland samen }\end{array}$ & 2,97 & $-5,24$ & 0,98 & 0,015 & 0,011 & $<0,001$ & 82 \\
\hline
\end{tabular}

3 De bepaling van het Pw-getal wordt door veel laboratoria als lastig ervaren. Bovendien kiezen laboratoria er steeds vaker voor om multinutriënten-extractievloeistoffen te gebruiken, om economische redenen. Een multinutriëntenextractievloeistof is $0,01 \mathrm{M} \mathrm{CaCl}_{2}$, dat wordt gebruikt voor de gelijktijdige bepaling van bijvoorbeeld stikstof, fosfaat en kalium, dat direct beschikbaar is voor het gewas. Dit zijn de belangrijkste redenen dat het Pw-getal vrijwel niet meer wordt bepaald en dat $\mathrm{P}-\mathrm{CaCl}_{2}$ daarvoor in de plaats is gekomen. 
Uiteindelijk is gekozen voor het model met de hoogste verklaarde variantie, waarbij het verschil tussen de gefitte en waargenomen waarde (het residu) geen verband vertoonde met de gefitte waarde (zie residuenplot in Bijlage 1 ). Dit was een exponentieel model, waarbij $\mathrm{P}-\mathrm{CaCl}_{2}$ log-getransformeerd is $\left[\ln \left(P-C_{2} C_{2}\right)=a+b^{*} D^{\wedge} P w\right]$. Dit model verklaarde circa $82 \%$ van de variantie. De coëfficiënten en standaardafwijking van de coëfficiënten van de relaties tussen $\mathrm{P}-\mathrm{CaCl}_{2}$ en $\mathrm{Pw}$-getal zijn weergegeven in Tabel 3. Het blijkt dat de regressiecoëfficiënten $a$, $b$ en $D$ weinig verschillen tussen akker- en tuinbouw en grasland. Dit suggereert dat een uniforme gecombineerde indicator gebruikt kan worden voor akkerbouw, tuinbouw en grasland. In Bijlage 3 wordt een verdere analyse beschreven van de getoetste statistische relaties tussen het $\mathrm{Pw}$-getal en $\mathrm{P}-\mathrm{CaCl}_{2}$.

Op basis van bodemchemische overwegingen kan worden gesteld dat het P-AL-getal (als capaciteitsindicator) ook toegepast kan worden voor akker- en tuinbouw en dat $\mathrm{P}-\mathrm{CaCl}_{2}$ (als intensiteitsindicator) ook toegepast kan worden voor grasland (CDM, 2015). Dit impliceert dat de gecombineerde indicator toegepast kan worden voor zowel grasland en bouwland. Het betekent echter niet dat noodzakelijkerwijze dezelfde klassengrenzen gebruikt moeten worden voor grasland en bouwland, al is dat hieronder in eerste instantie wel gedaan, vooral ook om na te gaan of vereenvoudiging van het stelstel en klassenindelingen mogelijk is.

De regressievergelijking in Tabel 3 is gebruikt om de huidige klassengrenzen van het Pw-getal in het stelsel van fosfaattoestand-afhankelijke fosfaatgebruiksnormen om te rekenen naar klassengrenzen voor $\mathrm{P}-\mathrm{CaCl}_{2}$. De klassengrenzen voor het P-AL-getal (voor grasland) zijn onveranderd gebleven. In Tabellen 4, 5 en 6 worden de grenzen gegeven voor $\mathrm{P}-\mathrm{CaCl}_{2}$ met tussen haakjes het $95 \%$ betrouwbaarheidsinterval. Deze tabellen hebben dezelfde vorm als Tabel 2 in de inleiding. In paragraaf 3.3. worden ook andere voorstellen voor klassenindelingen besproken.

Bij vergelijking van Tabel 4, 5 en 6 blijkt dat de regressievergelijking voor akker- en tuinbouw, grasland en alle landbouwgrond samen tot geringe verschillen in klassengrenzen voor $\mathrm{P}-\mathrm{CaCl}_{2}$ leiden. Een Pw-getal van $25 \mathrm{mg} \mathrm{P}_{2} \mathrm{O}_{5} \mathrm{~L}^{-1}$ komt overeen met een $\mathrm{P}-\mathrm{CaCl}_{2}$ waarde van 0,7 à $0,8 \mathrm{mg} \mathrm{P} \mathrm{kg}^{-1}$. Een Pw-getal van $36 \mathrm{mg} \mathrm{P}_{2} \mathrm{O}_{5} \mathrm{~L}^{-1}$ komt overeen met een $\mathrm{P}-\mathrm{CaCl}_{2}$ waarde van 1,4 à $1,5 \mathrm{mg} \mathrm{P} \mathrm{kg}^{-1}$. Een Pw-getal van 55 mg $\mathrm{P}_{2} \mathrm{O}_{5} \mathrm{~L}^{-1}$ komt overeen met een $\mathrm{P}-\mathrm{CaCl}_{2}$ waarde van 3,1 à $3,2 \mathrm{mg} \mathrm{P} \mathrm{kg}^{-1}$. Het $95 \%$ betrouwbaarheidsinterval ( \pm tweemaal de standaardafwijking) van de berekende klassengrenzen is breed.

In Tabel 4, 5 en 6 is voor iedere gecombineerde klasse het percentage monsters weergegeven dat in een bepaalde klasse valt (percentage van het totaal aantal van 55.339 grondmonsters uit de Eurofinsdatabase). Het aantal monsters per klasse is een grove maat voor het areaal per klasse. Het aantal monsters is voor de klassen arm en laag gering in deze voorstellen. Bij grasland zijn er meer monsters in de klassen arm en laag dan bij bouwland. Bij bouwland valt meer dan de helft van het aantal monsters in de klasse hoog, en bij grasland een derde deel.

\section{Tabel 4}

Voorstel voor klassengrenzen van de fosfaattoestand van bouwland met een gecombineerde indicator ( $P$ - $\mathrm{CaCl}_{2}$-SFA als intensiteitsindicator en $P$-AL-getal als capaciteitsindicator), op basis van de grenzen in het gebruiksnormenstelsel en de regressievergelijking voor de omrekening van $P$ w-getal in $P-C_{2} C_{2}$ vermeld in Tabel 3. De getallen tussen haakjes geven het traject weer van 95\% betrouwbaarheidsinterval van de klassengrenzen voor $\mathrm{P}-\mathrm{CaCl}_{2}$. Voor iedere gecombineerde klasse is het percentage van het totaal aantal monsters op bouwland weergegeven, op basis van de Eurofinsdatabase. Percentages zijn afgerond; het getal 0 betekent $<0,49 \%$.

\begin{tabular}{|c|c|c|c|c|}
\hline \multirow{2}{*}{$\begin{array}{l}\mathrm{P}-\mathrm{CaCl}_{2}-\mathrm{SFA} \text {, } \\
\text { mg P kg-1 } \\
\text { gemiddelde ( } \pm 2 \times \text { standaardafwijking) }\end{array}$} & \multicolumn{4}{|c|}{$\begin{array}{l}\text { Percentage monsters per fosfaattoestandsklasse, uitgedrukt } \\
\text { in P-AL-getal, } \mathrm{mg} \mathrm{P}_{2} \mathrm{O}_{5}(100 \mathrm{~g})^{-1}\end{array}$} \\
\hline & $<16$ & $16-27$ & $27-50$ & $>50$ \\
\hline $0,7-1,4(0,3-3,0)$ & 0 & 1 & 10 & 7 \\
\hline $1,4-3,1(0,6-6,8)$ & 0 & 1 & 14 & 19 \\
\hline
\end{tabular}




\section{Tabel 5}

Voorstel voor klassengrenzen van de fosfaattoestand van grasland met een gecombineerde indicator ( $P$ - $\mathrm{CaCl}_{2}$-SFA als intensiteitsindicator en P-AL-getal als capaciteitsindicator), op basis van de grenzen in het gebruiksnormenstelsel en de regressievergelijking voor de omrekening van $\mathrm{Pw}$-getal in $\mathrm{P}-\mathrm{CaCl}_{2}$ vermeld in Tabel 3. De getallen tussen haakjes geven het traject weer van 95\% betrouwbaarheidsinterval van de klassengrenzen voor $\mathrm{P}-\mathrm{CaCl}_{2}$. Voor iedere gecombineerde klasse is het percentage van het totaal aantal monsters op grasland weergegeven, op basis van de Eurofinsdatabase. Percentages zijn afgerond; het getal 0 betekent $<0,49 \%$.

\begin{tabular}{|c|c|c|c|c|}
\hline \multirow{2}{*}{$\begin{array}{l}\mathrm{P}-\mathrm{CaCl}_{2}-\mathrm{SFA} \text {, } \\
\mathrm{mg} \mathrm{P} \mathrm{kg}{ }^{-1} \\
\text { gemiddelde ( } \pm 2 \times \text { standaardafwijking) }\end{array}$} & \multicolumn{4}{|c|}{$\begin{array}{l}\text { Percentage monsters per fosfaattoestandsklasse, uitgedrukt } \\
\text { in P-AL-getal, } \mathrm{mg} \mathrm{P}_{2} \mathrm{O}_{5}(100 \mathrm{~g})^{-1}\end{array}$} \\
\hline & $<16$ & $16-27$ & $27-50$ & $>50$ \\
\hline$<0,8(0,4-1,6)$ & 3 & 8 & 7 & 0 \\
\hline $0,8-1,5(0,4-3,0)$ & 1 & 6 & 17 & 3 \\
\hline $1,5-3,2(0,7-6,6)$ & 0 & 3 & 19 & 12 \\
\hline$>3,2(1,6-6,6)$ & 0 & 1 & 6 & 15 \\
\hline
\end{tabular}

\section{Tabel 6}

Voorstel voor klassengrenzen van de fosfaattoestand van bouwland en grasland met een gecombineerde indicator ( $\mathrm{P}$ - $\mathrm{CaCl}_{2}$-SFA als intensiteitsindicator en P-AL-getal als capaciteitsindicator), op basis van de grenzen in het gebruiksnormenstelsel en de regressievergelijking voor de omrekening van $\mathrm{Pw}$-getal in $\mathrm{P}-\mathrm{CaCl}_{2}$ vermeld in Tabel 3. De getallen tussen haakjes geven het traject weer van $95 \%$ betrouwbaarheidsinterval van de klassengrenzen voor $\mathrm{P}-\mathrm{CaCl}_{2}$. Voor iedere gecombineerde klasse is het percentage van het totaal aantal monsters op landbouwgrond (grasland + bouwland) weergegeven, op basis van de Eurofins-database. Percentages zijn afgerond; het getal 0 betekent $<0,49 \%$.

\begin{tabular}{|c|c|c|c|c|}
\hline \multirow{2}{*}{$\begin{array}{l}\mathrm{P}-\mathrm{CaCl}_{2}-\mathrm{SFA} \\
\mathrm{mg} \mathrm{P} \mathrm{kg} \\
\text { gemiddelde ( } \pm 2 \times \text { standaardafwijking) }\end{array}$} & \multicolumn{4}{|c|}{$\begin{array}{l}\text { Percentage monsters per fosfaattoestandsklasse, uitgedrukt } \\
\text { in P-AL-getal, } \mathrm{Mg} \mathrm{P}_{2} \mathrm{O}_{5}(100 \mathrm{~g})^{-1}\end{array}$} \\
\hline & $<16$ & $16-27$ & $27-50$ & $>50$ \\
\hline$<0,8(0,4-1,6)$ & 2 & 6 & 7 & 1 \\
\hline $0,8-1,4(0,4-3,0)$ & 0 & 3 & 13 & 5 \\
\hline $1,4-3,1(0,7-6,6)$ & 0 & 2 & 17 & 15 \\
\hline$>3,1(1,5-6,6)$ & 0 & 1 & 7 & 21 \\
\hline
\end{tabular}

\subsection{Implicaties van voorgestelde klassengrenzen voor de fosfaatgebruiksruimte}

\subsubsection{Beschikbare gegevens}

De klassengrenzen voor de fosfaattoestand-afhankelijke fosfaatgebruiksnormen bepalen mede de grootte van de totale fosfaatgebruiksruimte in Nederland. In deze paragraaf worden de gebruikte data en werkwijze voor de berekening van het effect van de voorgesteld klassengrenzen (in hoofdstuk 3.1) op de fosfaatgebruiksruimte besproken. Het databestand Eurofins Agro bevat meetgegevens betreffende de P-toestand in de bodem (onder andere P-AL-getal, $\mathrm{Pw}$-getal en $\mathrm{P}-\mathrm{CaCl}_{2}$ ) per perceel en de postcode van het perceel op wijkniveau (alleen de cijfers), maar de grootte van de percelen is niet bekend. Met het databestand van Eurofins kan een omrekening worden gemaakt van Pw-getal naar $\mathrm{P}-\mathrm{CaCl}_{2}$, maar er kan geen nauwkeurige fosfaatgebruiksruimte worden berekend (omdat de oppervlaktes van de geanalyseerde en niet-geanalyseerde percelen niet bekend zijn).

Daarom is ook gebruikgemaakt van de recentste gegevens over de fosfaattoestand van landbouwgrond, zoals geregistreerd door RVO.nl (databestand 2015). Dit bestand geeft aan welke fosfaatgebruiksnormen op welk perceel van toepassing was in 2015. Dit bestand bevat op perceelniveau gegevens over de oppervlakte, het type landgebruik (grasland, bouwland of overig), 
landgebruiksdoel (agrarisch of natuurlijk grasland) en P-AL-getal of Pw-getal. Van ieder perceel is de postcode op wijkniveau gegeven (alleen de cijfers). Ook is per perceel aangegeven of de grond P-fixerend is (zie ook Tabel 7); P-fixerende gronden vallen in de waarderingsklasse 'arm'.

\section{Tabel 7}

Beschikbare gegevens in de bestanden van Eurofins Agro en RVO.nl; de aanduiding 'X' betekent dat de informatie beschikbaar is; de aanduiding '-' betekent dat de informatie niet beschikbaar is.

\begin{tabular}{|c|c|c|}
\hline Gegevens voor berekening fosfaatgebruiksruimte & Eurofins Agro & RVO \\
\hline Landgebruik & $\mathrm{X}$ & $\mathrm{X}$ \\
\hline Postcode & $\mathrm{x}$ & $\mathrm{x}$ \\
\hline P-AL-getal, mg $\mathrm{P}_{2} \mathrm{O}_{5}(100 \mathrm{~g})^{-1}$ & $x$ & $\mathrm{X}$ \\
\hline Pw-getal, $\mathrm{mg} \mathrm{P}_{2} \mathrm{O}_{5} \mathrm{~L}^{-1}$ & $x$ & $x$ \\
\hline Aanwijzing P-fixerende grond, - & - & $\mathrm{X}$ \\
\hline
\end{tabular}
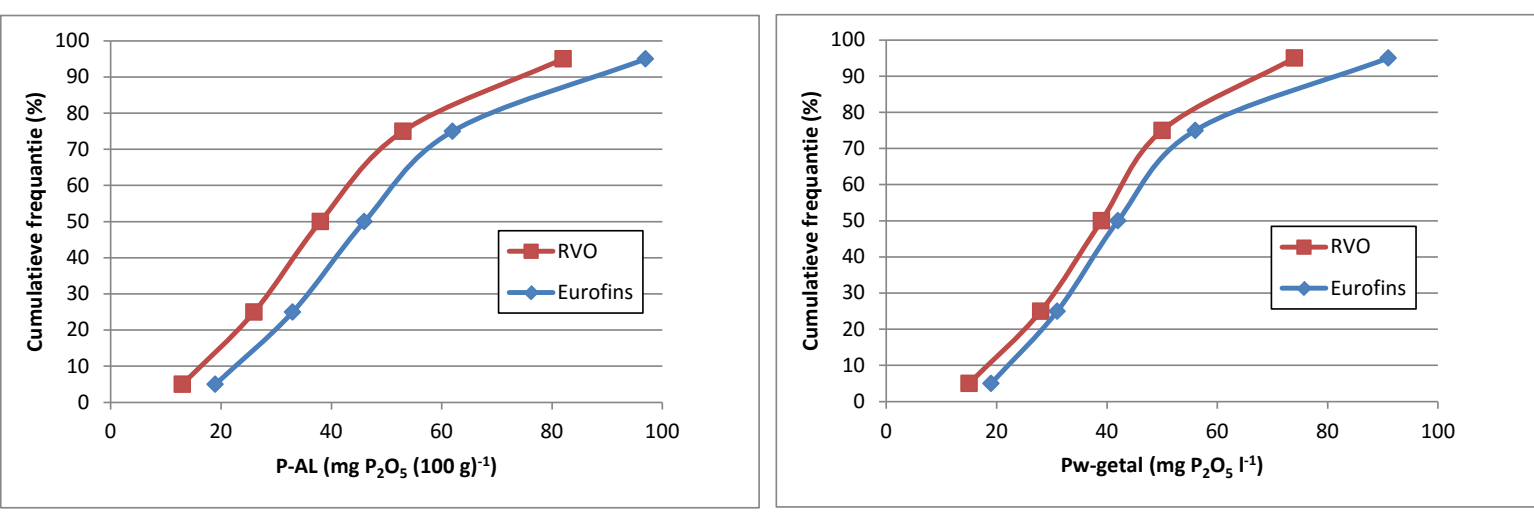

Figuur 3 Cumulatieve frequentieverdelingen van P-AL-getal (links) en Pw-getal (rechts) uit de bestanden van RVO en Eurofins Agro.

In Figuur 3 zijn de cumulatieve frequentieverdelingen te zien van het P-AL-getal en Pw-getal voor beide datasets. In de dataset van Eurofins Agro zijn de percentielwaarden van het P-AL-getal en Pwgetal hoger dan in het bestand van RVO.nl, maar de vorm van de frequentieverdelingen is vergelijkbaar. Dit betekent dat de waarden voor de fosfaattoestand gemiddeld genomen hoger zijn in het Eurofins-bestand dan in het RVO-bestand. Verschillen zijn groter bij grasland (P-AL-getal) dan bij bouwland ( $\mathrm{Pw}$-getal). Beide databestanden geven waarschijnlijk geen representatief beeld van de fosfaattoestand in Nederland, omdat beide bestanden niet zijn verkregen via een representatieve steekproef. Het RVO-databestand is de formele basis voor de afleiding van fosfaatgebruiksnormen.

De percentielwaarden van het P-AL-getal en het Pw-getal blijken in alle provincies hoger te zijn in het databestand van Eurofins dan in dat van RVO.nl, behalve in Friesland (Tabel 8). Het aantal monsters per provincie verschilt gemiddeld een factor drie tussen de twee databestanden, variërend van minder dan een factor twee (voor Limburg) tot meer dan een factor vijf (voor Friesland) (Tabel 8). Deze verschillen worden deels verklaard door de activiteiten van andere laboratoria in de markt, zoals het Agrarisch Laboratorium Noord-Nederland (ALNN) in Friesland. De gemiddeld lagere waarden voor de fosfaattoestand in het databestand van RVO.nl kan worden verklaard door het achterliggende doel van de waarden in het databestand van RVO.nl. Opgave van een hoge fosfaattoestand bij RVO.nl heeft weinig waarde voor een landbouwer, omdat een hoge fosfaattoestand automatisch resulteert in een lage fosfaatgebruiksnorm. Veel boeren kiezen ervoor om percelen niet te bemonsteren, omdat (i) ze aannemen dat de fosfaattoestand hoog is, en/of (ii) het analyseren van de fosfaattoestand niet veel waarde heeft, omdat de verschillen in fosfaatgebruiksnormen tussen klassen relatief beperkt zijn (Tabel 1, Inleiding). Percelen die wel worden bemonsterd en geanalyseerd, hebben daardoor 
gemiddeld genomen een lagere fosfaattoestand dan de percelen die niet zijn bemonsterd. Ook valt op dat de gemiddelde waarden in Tabel 8 hoger zijn dan de mediane waarden, m.a.w. de frequentieverdelingen zijn scheef verdeeld naar rechts (zie ook Figuur 2).

\section{Tabel 8}

Aantallen monsters, gemiddelde en mediane waarden voor P-AL-getal en Pw-getal per provincie van de databestanden van Eurofins Agro en RVO. Gemiddelde waarden op basis van aantal monsters per provincie.

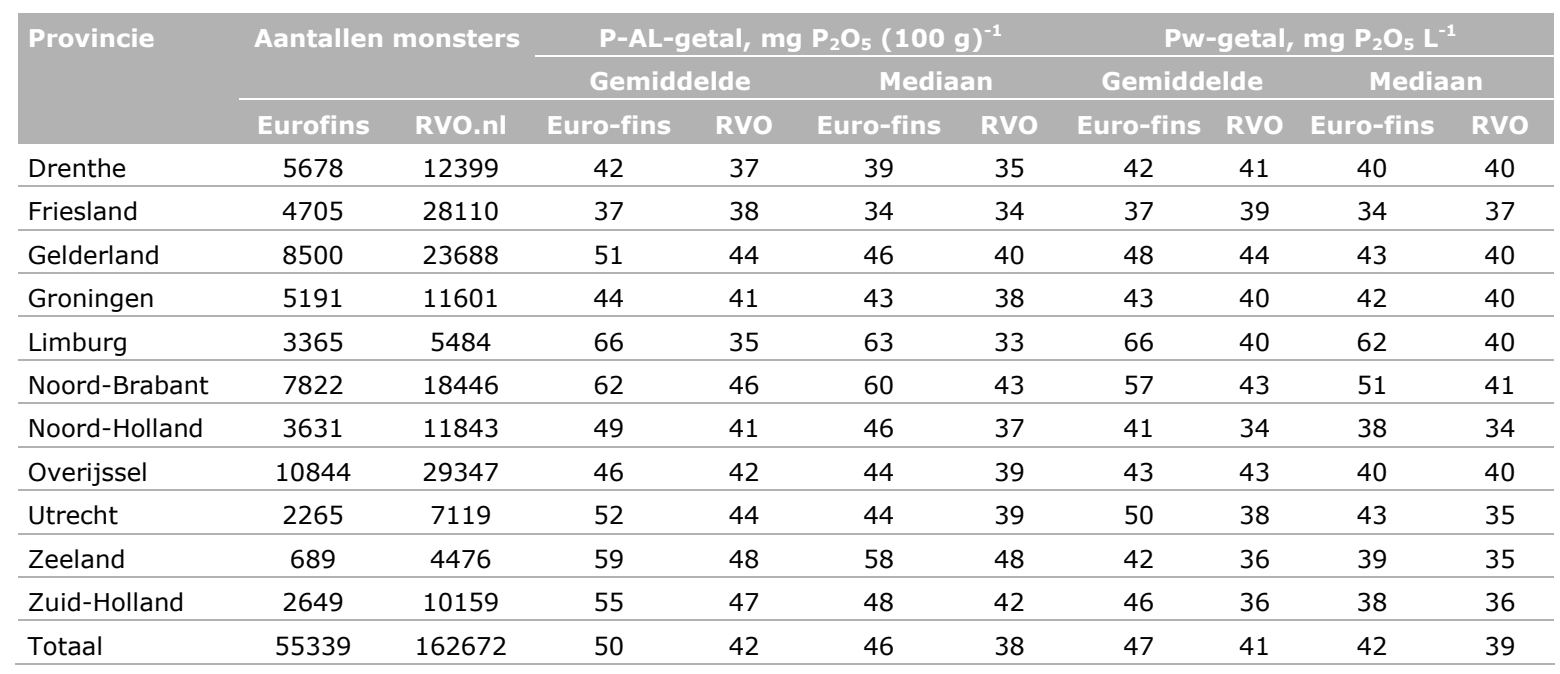

De perceelsgrootte, fosfaattoestand en fosfaatgebruiksnormen bepalen samen de fosfaatgebruiksruimte. De perceelsgrootte van de onderzochte percelen in het RVO.nl bestand varieert sterk (Tabel 9). Percelen grasland zijn gemiddeld wat kleiner dan de percelen bouwland, maar dat geldt niet voor natuurlijk grasland. De perceelsgrootte bij een percentielwaarde van $95 \%$ is 23 ha voor grasland, 64 ha voor natuurlijk grasland en 51 ha voor bouwland. Dit impliceert dat $5 \%$ van de onderzochte percelen ( $=8133$ percelen) een oppervlakte heeft dat groter is dan respectivelijk 23,64 en 51 ha. Deze grote variatie in perceelsgrootte en de scheve frequentieverdeling van de perceelsgrootte impliceren dat de effecten van een kleine verschuiving in de fosfaattoestand kleine of grootte effecten kunnen hebben op de fosfaatgebruiksruimte, afhankelijk van de perceelsgrootte van de onderzochte percelen.

\section{Tabel 9}

Percentielwaarden van de perceelsgrootte per landgebruikstype in het RVO-bestand, in ha.

\begin{tabular}{lccc} 
Percentielwaarde, \% & Grasland & Bouwland \\
\cline { 2 - 3 } 5 & Agrarisch & Natuurlijk & 0,8 \\
\hline 25 & 0,4 & 0,4 & 2,3 \\
\hline 50 & 1,9 & 1,8 & 4,2 \\
\hline 75 & 3,6 & 5,5 & 9,0 \\
\hline 5 & 7,1 & 16,9 & 51,2 \\
\hline
\end{tabular}

\subsubsection{Berekeningswijze fosfaatgebruiksruimte}

De fosfaatgebruiksruimte is bepaald op basis van gegevens per perceel over de fosfaattoestand, oppervlak en landgebruik, zoals afgeleid uit het RVO-databestand, en de bijbehorende fosfaatgebruiksnormen uit Tabel 1 . Een perceel met de code 'fixerend' heeft de fosfaattoestandsklasse 'arm' gekregen. Aan percelen zonder bekende waarden voor P-AL-getal en/of Pw-getal is de fosfaattoestandsklasse 'hoog' toegekend. Voor natuurlijke graslanden is een fosfaatgebruiksnorm 
aangehouden van $70 \mathrm{~kg} \mathrm{P}_{2} \mathrm{O}_{5}$ per ha per jaar indien het landgebruik 'grasland' was en $20 \mathrm{~kg} \mathrm{P}_{2} \mathrm{O}_{5}$ per ha per jaar als het landgebruik als 'overig' was vermeld.

In het bestand van Eurofins Agro is niet aangegeven of grasland gebruikt werd als 'natuurgrasland' en of de grond 'fosfaat-fixerend' was of niet. Ook is het areaal van de geanalyseerde en nietgeanalyseerde percelen niet bekend. Toch is ook een schatting gemaakt van de totale fosfaatgebruiksruimte op basis van de Eurofins-database. Daartoe is per postcode en per landgebruikstype het percentage monsters in de waarderingsklassen arm, laag, neutraal en hoog representatief verondersteld voor het areaal landbouwgrond met die waarderingsklassen in het betreffende postcodegebied. Met andere woorden, er is verondersteld dat de beschikbare analysegegevens afkomstig zijn van een representatieve steekproef per postcodegebied. De postcodegebieden zijn in Figuur 4 weergegeven.

Het blijkt dat de arealen landbouwgrond in de bestanden verschillen. Het berekende areaal landbouwgrond voor alle postcodes in het Eurofins-bestand is kleiner dan het areaal landbouwgrond in het RVO-bestand. Voor de percelen die het verschil in areaal bepalen, is verondersteld dat de fosfaattoestand niet bekend is en dat deze percelen derhalve de laagste fosfaatgebruiksnorm krijgen toegewezen.

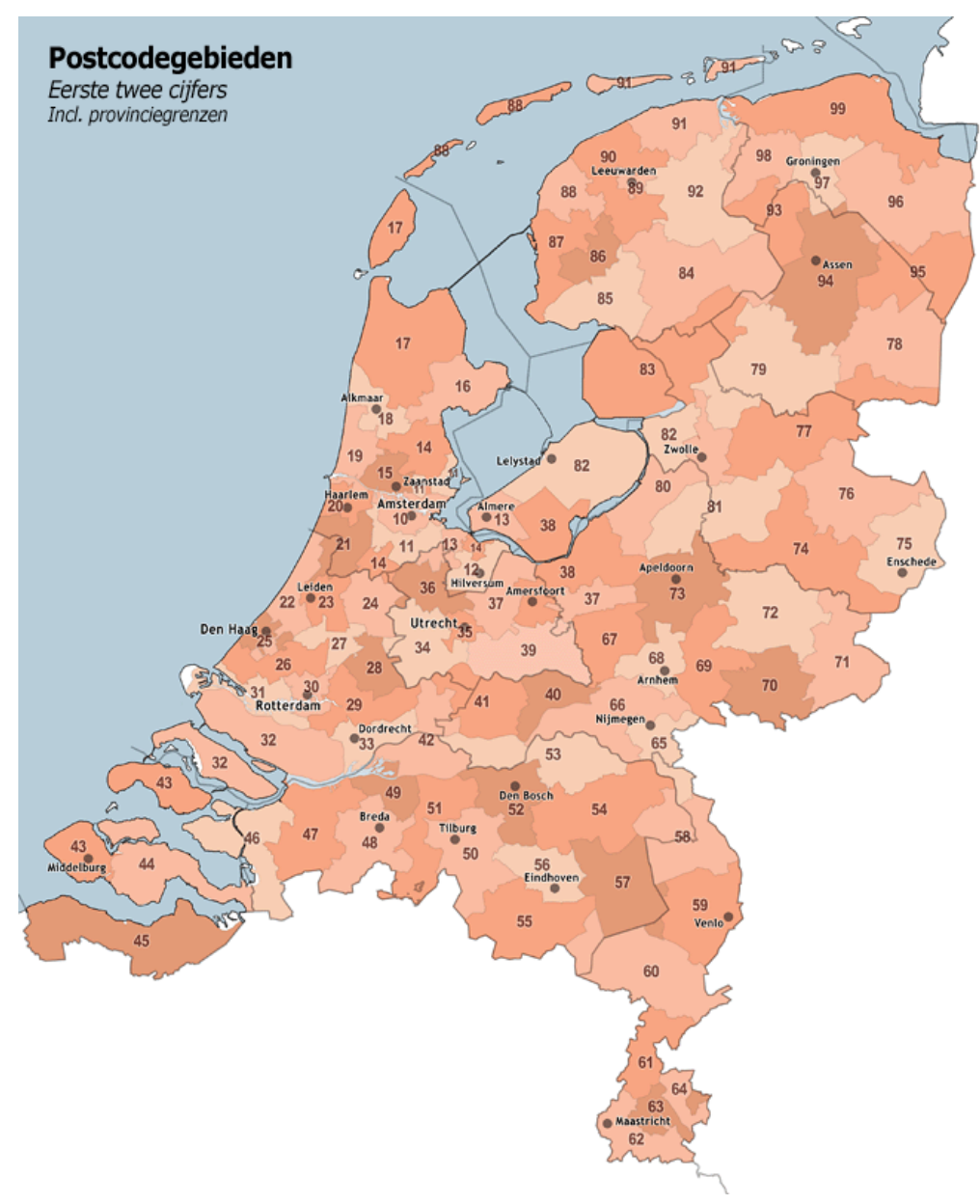

Figuur 4 Postcodegebieden op basis van de eerste twee cijfers van de postcode. Bron: https://nl.wikipedia.org/wiki/Postcodes_in_Nederland

\subsubsection{Berekende fosfaatgebruiksruimte}

Als de fosfaatgebruiksnormen worden toegekend op basis van de huidige klassenindeling met P-ALgetal en Pw-getal, dan is de totale fosfaatgebruiksruimte van bouwland en grasland samen 131 miljoen $\mathrm{kg} \mathrm{P}_{2} \mathrm{O}_{5}$ (op basis van RVO-gegevens). Het wel of niet meenemen van natuurlijk grasland scheelt 3 miljoen $\mathrm{kg} \mathrm{P}_{2} \mathrm{O}_{5}$ in de gebruiksruimte (Tabel 10). 
De fosfaatgebruiksruimte is ook berekend onder de aanname dat alle landbouwgrond de laagste fosfaatgebruiksnorm zou krijgen toegekend ( $50 \mathrm{~kg} \mathrm{P}_{2} \mathrm{O}_{5}$ per ha voor bouwland en $80 \mathrm{~kg}$ voor grasland), of juist de hoogste fosfaatgebruiksnorm zou krijgen toegekend (120 kg $\mathrm{P}_{2} \mathrm{O}_{5}$ per ha voor zowel grasland als bouwland). Deze twee uitersten geven een beeld van de potentiële marges van de totale fosfaatgebruiksruimte. Het verschil tussen de laagste en hoogste fosfaatgebruiksnorm bedraagt bijna 100 miljoen $\mathrm{kg} \mathrm{P}_{2} \mathrm{O}_{5}$ per jaar. Het verschil tussen de laagste schatting en die op basis van de actuele fosfaattoestand-afhankelijke fosfaatgebruiksnormen bedraagt slechts 14 miljoen kg $\mathrm{P}_{2} \mathrm{O}_{5}$. Dit geeft aan dat veel percelen een relatief hoge fosfaattoestand hebben en dat het effect van de fosfaattoestand-afhankelijke fosfaatgebruiksnormen op de totale fosfaatgebruiksruimte in de huidige situatie beperkt is.

De berekende fosfaatgebruiksruimte is circa 10 miljoen $\mathrm{kg}$ fosfaat lager op basis van Eurofinsgegevens dan op basis van RVO-gegevens (Tabel 10). Dit verschil wordt mede veroorzaakt door het feit dat het totale landbouwareaal van de bekende postcodegebieden in het Eurofins-bestand kleiner is dan in het RVO-bestand. Indien wordt verondersteld dat voor de ontbrekende percelen geen fosfaattoestand bekend is en dat daardoor de laagste fosfaatgebruiksnorm van toepassing is, neemt de fosfaatgebruiksruimte toe tot 137 miljoen $\mathrm{kg} \mathrm{P}_{2} \mathrm{O}_{5}$ per jaar. Dat is iets meer dan volgens de schatting op basis van het RVO-databestand, en dat is waarschijnlijk het gevolg van het verschil in berekeningswijze van de fosfaatgebruiksruimte en van de verschillen in frequentieverdelingen van de fosfaattoestand (Figuur 3).

Tabel 10

Totale fosfaatgebruiksruimte voor grasland, bouwland en alle landbouwgrond in Nederland, berekend op basis van arealen en gemiddelde fosfaattoestand (Pw-getal en P-AL-getal) per perceel (RVO-data voor 2015) en de fosfaatgebruiksnormen voor 2016 (Tabel 1). Ook is de fosfaatgebruiksruimte berekend op basis van Eurofins-gegevens per postcodegebied (zie tekst).

\begin{tabular}{|c|c|c|c|c|}
\hline \multirow[t]{2}{*}{ Nr } & \multirow[t]{2}{*}{ Beschrijving } & \multicolumn{3}{|c|}{ Gebruiksruimte (miljoen $\mathrm{kg} \mathrm{P}_{2} \mathrm{O}_{5}$ ) } \\
\hline & & Grasland & Bouwland & Totaal \\
\hline \multicolumn{5}{|c|}{ Fosfaatgebruiksruimte berekend per perceel op basis van enkel RVO-gegevens } \\
\hline 2 & Gebruiksruimte landbouwgrond + natuurgrasland & 85 & 49 & 134 \\
\hline 3 & $\begin{array}{l}\text { Gebruiksruimte bij toepassing laagste fosfaatgebruiksnormen ( } 50 \mathrm{~kg} / \mathrm{ha} \text { voor } \\
\text { alle bouwland en alle grasland ( } 80 \mathrm{~kg} \mathrm{P}_{2} \mathrm{O}_{5} \text { per ha) }\end{array}$ & 79 & 41 & 120 \\
\hline 4 & $\begin{array}{l}\text { Gebruiksruimte bij toepassing hoogste fosfaatgebruiksnorm ( } 120 \mathrm{~kg} / \mathrm{ha} \text { ) voor } \\
\text { alle landbouwgrond }\end{array}$ & 118 & 99 & 217 \\
\hline
\end{tabular}

\begin{tabular}{llccc}
\hline \multicolumn{4}{l}{ Fosfaatgebruiksruimte berekend per postcodegebied op basis van fosfaattoestand gegevens van Eurofins } \\
\hline 5 & Gebruiksruimte landbouwgrond + natuurgrasland & 77 & 45 & 122 \\
\hline 5 & Niet opgegeven areaal (zie tekst) & 12 & 3 \\
\hline 5 & Totaal & 89 & 45 & 137 \\
\hline
\end{tabular}

Tabel 11, 12 en 13 geven de fosfaatgebruiksruimte weer voor respectievelijk bouwland, grasland en alle landbouwgrond, per waarderingsklasse voor de gecombineerde indicator $\mathrm{P}-\mathrm{CaCl}_{2}$ en $\mathrm{P}-\mathrm{AL}-\mathrm{getal}$. De klassengrenzen voor de fosfaattoestand van de bodem zijn zoals voorgesteld in Tabel 4, 5 en 6 . De fosfaatgebruiksruimte is afgeleid op basis van het Eurofins-bestand, volgens de procedure die hiervoor is beschreven. De totale fosfaatgebruiksruimte van alle landbouwgrond is 122 miljoen $\mathrm{kg}_{2} \mathrm{O}_{5}$ (en niet 137 miljoen kg zoals in Tabel 10 is weergegeven, omdat de niet opgegeven percelen niet zijn meegenomen in deze analyse).

De fosfaatgebruiksruimte in de waarderingsklasse $\mathrm{P}-\mathrm{AL}$-getal $<16 \mathrm{mg} \mathrm{P}_{2} \mathrm{O}_{5}(100 \mathrm{~g})^{-1}$ is gering, vooral bij bouwland. De fosfaatgebruiksruimte in de waarderingsklasse $\mathrm{P}-\mathrm{CaCl}_{2}<0,7$ à $0,8 \mathrm{mg} \mathrm{P} \mathrm{kg}^{-1}$ is vrij groot. Dit impliceert dat een lage waarde van $\mathrm{P}-\mathrm{CaCl}_{2}$ kan voorkomen met lage en hoge waarden voor het P-AL-getal, en onderstreept in zekere zin de waarde van een gecombineerde indicator. Een hoge waarde voor $\mathrm{P}-\mathrm{CaCl}_{2}$ komt niet frequent voor met een laag P-AL-getal, maar een hoog P-AL-getal wel met zowel relatief lage en hoge waarden voor $\mathrm{P}-\mathrm{CaCl}_{2}$. 
Tabel 11

Fosfaatgebruiksruimte op bouwland (in miljoen $\mathrm{kg}_{2} \mathrm{P}_{2} \mathrm{O}_{5}$ per jaar) bij gebruik van de klassenindeling voor de fosfaattoestand vermeld in Tabel 4 en fosfaatgebruiksnormen voor 2016 (Tabel 1).

Fosfaatgebruiksruimten zijn afgeleid op basis van het Eurofins-bestand (zie tekst).

\begin{tabular}{|c|c|c|c|c|c|}
\hline \multirow[t]{2}{*}{$\begin{array}{l}\mathrm{P}-\mathrm{CaCl}_{2}-\mathrm{SFA} \text {, } \\
\mathrm{mg} \mathrm{P} \mathrm{kg}{ }^{-1}\end{array}$} & \multicolumn{5}{|c|}{ 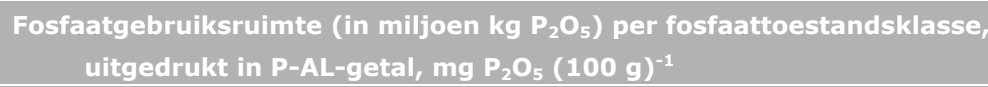 } \\
\hline & $<16$ & $16-27$ & $27-50$ & $>50$ & Totaal \\
\hline$<0,7$ & 0,91 & 2,57 & 4,87 & 0,94 & 9,3 \\
\hline $0,7-1,4$ & 0,07 & 0,61 & 5,27 & 4,87 & 10,8 \\
\hline $1,4-3,1$ & 0,02 & 0,31 & 5,55 & 7,89 & 13,8 \\
\hline$>3,1$ & 0,03 & 0,29 & 2,32 & 8,73 & 11,4 \\
\hline Totaal, miljoen $\mathrm{kg} \mathrm{P}_{2} \mathrm{O}_{5}$ & 1,02 & 3,79 & 18,0 & 22,4 & 45,2 \\
\hline
\end{tabular}

\section{Tabel 12}

Fosfaatgebruiksruimte op grasland (in miljoen $\mathrm{kg}_{2} \mathrm{O}_{5}$ per jaar) bij gebruik van de klassenindeling voor de fosfaattoestand vermeld in Tabel 5 en fosfaatgebruiksnormen voor 2016 (Tabel 1). Fosfaatgebruiksruimten zijn afgeleid op basis van het Eurofins-bestand (zie tekst).

\begin{tabular}{|c|c|c|c|c|c|}
\hline \multirow[t]{2}{*}{$\begin{array}{l}\mathrm{P}-\mathrm{CaCl}_{2}-\mathrm{SFA} \text {, } \\
\mathrm{mg} \mathrm{P} \mathrm{kg}{ }^{-1}\end{array}$} & \multicolumn{5}{|c|}{ 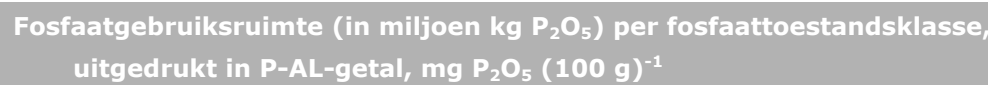 } \\
\hline & $<16$ & $16-27$ & $27-50$ & $>50$ & Totaal \\
\hline$<0,8$ & 2,37 & 8,84 & 6,17 & 0,24 & 17,6 \\
\hline $0,8-1,5$ & 0,58 & 5,03 & 12,9 & 2,11 & 20,7 \\
\hline $1,5-3,2$ & 0,32 & 2,43 & 14,4 & 7,39 & 24,5 \\
\hline$>3,2$ & 0,01 & 0,52 & 4,19 & 9,41 & 14,2 \\
\hline Totaal, miljoen $\mathrm{kg} \mathrm{P}_{2} \mathrm{O}_{5}$ & 3,37 & 16,8 & 27,7 & 19,1 & 77,0 \\
\hline
\end{tabular}

\section{Tabel 13}

Fosfaatgebruiksruimte op bouwland en grasland samen (in miljoen $\mathrm{kg} \mathrm{P}_{2} \mathrm{O}_{5}$ per jaar) bij gebruik van de klassenindeling voor de fosfaattoestand vermeld in Tabel 6 en fosfaatgebruiksnormen voor 2016 (Tabel 1). Fosfaatgebruiksruimten zijn afgeleid op basis van het Eurofins-bestand (zie tekst).

\begin{tabular}{|c|c|c|c|c|c|}
\hline \multirow[t]{2}{*}{$\begin{array}{l}\mathrm{P}-\mathrm{CaCl}_{2}-\mathrm{SFA} \text {, } \\
\mathrm{mg} \mathrm{P} \mathrm{kg}^{-1}\end{array}$} & \multicolumn{5}{|c|}{$\begin{array}{l}\text { Fosfaatgebruiksruimte (in miljoen } \mathrm{kg}_{2} \mathrm{O}_{5} \text { ) per fosfaattoestandsklasse, } \\
\text { uitgedrukt in P-AL-getal, } \mathrm{mg} \mathrm{P}_{2} \mathrm{O}_{5}(100 \mathrm{~g})^{-1}\end{array}$} \\
\hline & $<16$ & $16-27$ & $27-50$ & $>50$ & Totaal \\
\hline$<0,8$ & 3,28 & 11,4 & 11,0 & 1,18 & 26,9 \\
\hline $0,8-1,4$ & 0,65 & 5,65 & 18,2 & 6,98 & 31,5 \\
\hline $1,4-3,1$ & 0,33 & 2,75 & 19,9 & 15,3 & 38,3 \\
\hline$>3,1$ & 0,13 & 0,81 & 6,51 & 18,1 & 25,6 \\
\hline Totaal, miljoen $\mathrm{kg} \mathrm{P}_{2} \mathrm{O}_{5}$ & 4,39 & 20,6 & 55,7 & 41,6 & 122 \\
\hline
\end{tabular}

Theoretisch is het mogelijk dat bij de overstap naar de gecombineerde indicator er gemiddeld genomen geen verandering in fosfaatgebruiksruimte optreedt, maar dat voor de helft van de percelen de gebruiksruimte toeneemt en voor de andere helft evenveel afneemt. Daarom is voor de percelen van het Eurofins-bestand nagegaan wat de verandering van waarderingsklasse voor de fosfaattoestand is wanneer de klasse wordt bepaald op basis van de gecombineerde indicator met zowel P-AL-getal en $\mathrm{P}-\mathrm{CaCl}_{2}$ ten opzichte van de huidige situatie op basis van $\mathrm{P}$-AL-getal voor grasland en Pw-getal voor bouwland. Daarbij is de volgende codering toegepast: $1=\operatorname{arm}, 2=$ laag, $3=$ neutraal en 4 = hoog. Wanneer het verschil tussen de gecombineerde indicator en de huidige methode groter dan nul is, is de waarderingsklasse bij de gecombineerde indicator hoger en is de gebruiksnorm dus lager.

In Figuur 5 is te zien dat 60 tot $70 \%$ van de percelen in dezelfde klasse blifft, en dat 30 tot $40 \%$ van de percelen in een andere klasse terechtkomt bij de overgang naar de gecombineerde indicator volgens het voorstel in Tabel 6 . Bij bouwland verschuift bijna $40 \%$ van de monsters naar een hogere 
fosfaattoestandsklasse (en dus lagere fosfaatgebruiksnorm), bij grasland is de verschuiving naar hogere en lagere fosfaattoestandsklassen ongeveer in evenwicht. De relatief forse nettoverschuiving bij bouwland is het effect van de doorwerking van het P-AL-getal op de afleiding van de waarderingsklassen; ervaring heeft geleerd dat de waardering van de fosfaattoestand van bouwland, op basis van Pw-getal, relatief lager is dan de waardering van de fosfaattoestand van grasland op basis van het P-AL-getal.
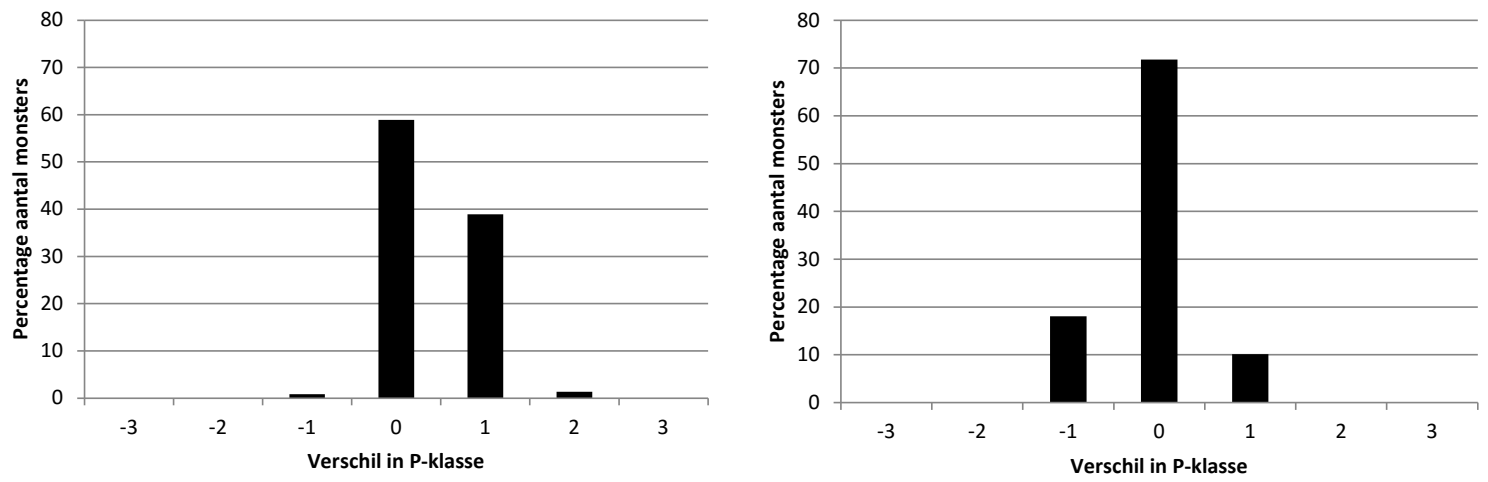

Figuur 5 Percentage van het totaal aantal monsters dat in een andere klasse van de fosfaattoestand terechtkomt bij invoering van de gecombineerde indicator met de klassengrenzen zoals voorgesteld in Tabel 6, voor bouwland (links) en grasland (rechts). Positieve waarden op de $x$-as geven een hogere fosfaattoestandsklasse weer (en dus een lagere fosfaatgebruiksnorm), en negatieve getallen een lagere fosfaattoestandsklasse (en dus hogere fosfaatgebruiksnorm).

\subsection{Alternatieve klassenindeling voor de gecombineerde indicator-set met P-AL-getal en $\mathrm{P}-\mathrm{CaCl}_{2}$}

De uitwerking van de klassenindeling voor een gecombineerde indicator-set met P-AL-getal en $\mathrm{P}-\mathrm{CaCl}_{2}$ in paragraaf 3.1 is gebaseerd op een tentatief voorstel van de Commissie Deskundigen Meststoffenwet (2015), samengevat in Tabel 2. Bij een totaal van $4 \times 4=16$ mogelijkheden (combinaties) is destijds door de CDM gekozen voor een symmetrisch schema met 3 combinaties voor de klasse arm, 3 combinaties voor de klasse laag, 7 combinaties voor de klasse neutraal en 3 combinaties voor de klasse hoog. Er is een gelijke diagnostische waarde toegekend aan de klassen van het P-AL-getal en aan de klassen van $\mathrm{P}-\mathrm{CaCl}_{2}$ wat betreft de fosfaatgebruiksnormen. In de studie van Bussink et al. (2014) wordt een grotere diagnostische waarde toegekend aan $\mathrm{P}-\mathrm{CaCl}_{2}$ dan aan het P-AL-getal. Bij een $\mathrm{P}-\mathrm{CaCl}_{2}$ van $0,5 \mathrm{mg} P$ per $\mathrm{kg}$ varieert de geadviseerde fosfaatgift volgens Bussink et al. (2014) slechts $25 \mathrm{~kg} \mathrm{P}_{2} \mathrm{O}_{5}$ per ha door een variatie in P-AL-getal van 10 tot 40 mg $\mathrm{P}_{2} \mathrm{O}_{5}$ per $100 \mathrm{gr}$, d.w.z. variatie in P-AL-getal leidt volgens Bussink et al. niet tot veel verschillen in behoefte aan fosfaatbemesting. Ter vergelijking: bij een P-AL-getal van 20 kan de geadviseerde fosfaatgift volgens Bussink et al. (2014) wel 90 à $120 \mathrm{~kg}$ $\mathrm{P}_{2} \mathrm{O}_{5}$ per ha verschillen door een variatie in $\mathrm{P}-\mathrm{CaCl}_{2}$ van 0,5 tot $4 \mathrm{mg} \mathrm{P}$ per $\mathrm{kg}$.

Toekenning van een grotere diagnostische waarde aan variatie in $\mathrm{P}-\mathrm{CaCl}_{2}$ dan aan variatie in het $\mathrm{P}-\mathrm{AL}$ getal leidt tot een meer asymmetrisch schema van de klassenindeling, zoals het voorbeeld van Tabel 14. Er zijn nu voor klasse arm 3 combinaties, voor klasse laag 4, voor klasse neutraal 5 en voor klasse hoog 4. Het effect van deze verandering op de fosfaatgebruiksruimte is gering, zowel voor bouwland als grasland, omdat het aantal percelen heel beperkt is in fosfaattoestandsklassen die veranderen (en daardoor de fosfaatgebruiksruimte ook). 
Tabel 14

Voorstel voor alternatieve klassenwaarderingen voor de fosfaattoestand van de bodem, waarbij $\mathrm{P}-\mathrm{CaCl}_{2}$ meer diagnostische waarde heeft voor de bepaling van fosfaatgebruiksnormen dan het $P$-AL-getal (zie tekst).

\begin{tabular}{|c|c|c|c|c|}
\hline \multirow[t]{2}{*}{$\begin{array}{l}\mathrm{P}-\mathrm{CaCl}_{2}-\mathrm{SFA} \text {, } \\
\mathrm{mg} \mathrm{P} \mathrm{kg}\end{array}$} & \multicolumn{4}{|c|}{$\begin{array}{l}\text { Waardering fosfaattoestandsklasse per klasse, } \\
\qquad \text { P-AL-getal, } \mathrm{mg} \mathrm{P}_{2} \mathrm{O}_{5}(100 \mathrm{~g})^{-1}\end{array}$} \\
\hline & $<16$ & $16-27$ & 27-50 & $>50$ \\
\hline $0,8-1,4$ & arm & laag & neutraal & neutraal \\
\hline $1,4-3,1$ & laag & neutraal & neutraal & hoog \\
\hline
\end{tabular}

In Tabel 15 is een voorstel weergegeven waarin de waarderingsklasse 'arm' enkel geldt voor een P-ALgetal $<16$, conform de huidige situatie. De waarderingsklasse 'arm' wordt dan beperkt tot gronden met een geringe capaciteit om fosfaat te leveren. De waarderingsklasse 'laag' is dan navenant groter. Toepassing van dit schema heeft minder effect op de fosfaatgebruiksruimte van bouwland dan op dat van grasland; bij grasland zijn er nu evenveel monsters die een klasse dalen en een klasse stijgen (Figuur 6). Uit deze analyse blijkt duidelijk dat een verandering van de waardering van de fosfaattoestand op de fosfaatgebruiksruimte een verschillend effect heeft voor bouwland dan voor grasland, omdat de verdeling van de monsters over de klassen arm, laag, neutraal en hoog verschillend is voor grasland en bouwland.

\section{Tabel 15}

Voorstel voor alternatieve klassenwaarderingen voor de fosfaattoestand van de bodem, waarbij $\mathrm{P}-\mathrm{CaCl}_{2}$ minder diagnostische waarde heeft voor de bepaling van fosfaatgebruiksnormen dan het $P$-AL-getal (zie tekst).

\begin{tabular}{|c|c|c|c|c|}
\hline \multirow[t]{2}{*}{$\begin{array}{l}\mathrm{P}-\mathrm{CaCl}_{2}-\mathrm{SFA} \text {, } \\
\mathrm{mg} \mathrm{P} \mathrm{kg}\end{array}$} & \multicolumn{4}{|c|}{$\begin{array}{l}\text { Waardering fosfaattoestandsklasse per klasse, } \\
\qquad \text { P-AL-getal, } \mathrm{mg} \mathrm{P}_{2} \mathrm{O}_{5}(100 \mathrm{~g})^{-1}\end{array}$} \\
\hline & $<16$ & $16-27$ & 27-50 & $>50$ \\
\hline $0,8-1,4$ & arm & laag & neutraal & neutraal \\
\hline $1,4-3,1$ & laag & neutraal & neutraal & hoog \\
\hline
\end{tabular}
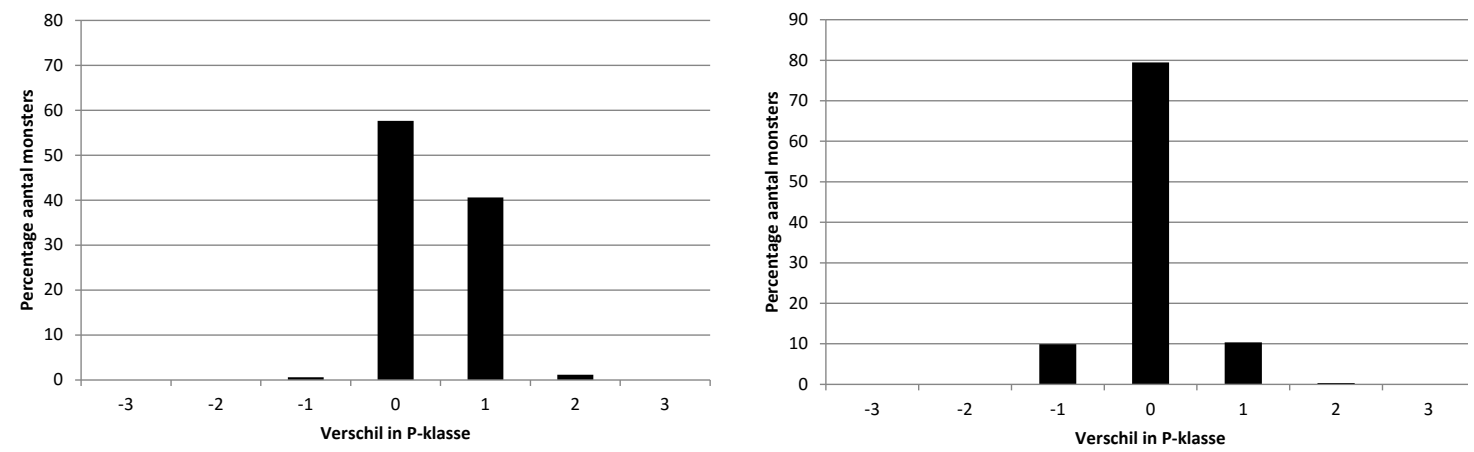

Figuur 6 Percentage van het totaal aantal monsters dat in een andere klasse van de fosfaattoestand terechtkomt bij invoering van de gecombineerde indicator met de klassengrenzen zoals voorgesteld in Tabel 15, voor bouwland (links) en grasland (rechts). Positieve waarden op de $x$-as geven weer een hogere fosfaattoestandsklasse (en dus een lagere fosfaatgebruiksnorm).

In Tabel 16 is een voorstel ontwikkeld waarbij de $\mathrm{P}-\mathrm{CaCl}_{2}$ en P-AL-getal verschillend zijn gewaardeerd voor grasland en bouwland, en waarbij ernaar is gestreefd om het aantal monsters per 
toestandsklasse overeen te laten komen met de oorspronkelijke situatie (waarin het Pw-getal de waardering van de fosfaattoestand van bouwland bepaalt en het P-AL-getal de waardering van de fosfaattoestand van grasland). Opvallend is dat veel combinaties van $\mathrm{P}-\mathrm{CaCl}_{2}$ en het P-AL-getal die in het oorspronkelijke voorstel (Tabel 2) werden gewaardeerd als 'hoog' nu als 'neutraal' worden gewaardeerd, en dat bij grasland combinaties van $\mathrm{P}-\mathrm{CaCl}_{2}$ en $\mathrm{P}-\mathrm{AL}$-getal die in het oorspronkelijke voorstel werden gewaardeerd als 'arm' nu als 'laag' worden gewaardeerd. Ook zijn klassen van laag naar neutraal verschoven bij grasland (Tabel 16). Opvallend aan deze schema's is dat de klasse 'hoog' zowel voor grasland als bouwland wordt bepaald door de combinatie $P-\mathrm{CaCl}_{2}>3,1 \mathrm{mg} \mathrm{P} \mathrm{kg}^{-1}$ en P-ALgetal $>50 \mathrm{mg} \mathrm{P}_{2} \mathrm{O}_{5}(100 \mathrm{~g})^{-1}$. De klasse 'arm' wordt bij grasland bepaald door de combinatie $\mathrm{P}-\mathrm{CaCl}_{2}$ $<0,8 \mathrm{mg} \mathrm{P} \mathrm{kg}^{-1}$ en $\mathrm{P}$-AL-getal $<16 \mathrm{mg} \mathrm{P}_{2} \mathrm{O}_{5}(100 \mathrm{~g})^{-1}$. Bij bouwland is dat door een combinatie van klassen van $\mathrm{P}-\mathrm{CaCL}_{2}$ en $\mathrm{P}-\mathrm{AL}-$ getal.

Figuur 7 geeft de verschuiving in het aantal monsters dat naar een andere klasse gaat. Bij bouwland blijft $78 \%$ van het aantal monsters nu in dezelfde klasse, $11 \%$ zakt een klasse en nog eens $11 \%$ stijgt een klasse. Bij grasland blijft nu 93\% van het aantal monsters in dezelfde klasse, 3\% zakt een klasse en $4 \%$ stijgt een klasse.

\section{Tabel 16}

Voorstel voor alternatieve klassenwaarderingen voor de fosfaattoestand van de bodem, waarbij $\mathrm{P}-\mathrm{CaCl}_{2}$ minder diagnostische waarde heeft voor de bepaling van fosfaatgebruiksnormen dan het $P$-AL-getal (zie tekst).

\begin{tabular}{|c|c|c|c|c|c|c|c|c|}
\hline \multirow{2}{*}{$\begin{array}{l}\mathrm{P}-\mathrm{CaCl}_{2}^{-} \\
\mathrm{SFA}, \\
\mathrm{mg} \mathrm{P} \mathrm{kg}\end{array}$} & \multicolumn{4}{|c|}{$\begin{array}{l}\text { Waardering fosfaattoestand bouwland } \\
\text { P-AL-getal, } \mathrm{mg} \mathrm{P}_{2} \mathrm{O}_{5}(100 \mathrm{~g})^{-1}\end{array}$} & \multicolumn{4}{|c|}{$\begin{array}{l}\text { Waardering fosfaattoestand grasland } \\
\text { P-AL-getal, } \mathrm{mg} \mathrm{P}_{2} \mathrm{O}_{5}(100 \mathrm{~g})^{-1}\end{array}$} \\
\hline & $<16$ & 16-27 & $27-50$ & $>50$ & $<16$ & $16-27$ & $27-50$ & $>50$ \\
\hline $0,8-1,4$ & arm & laag & laag & neutraal & laag & laag & neutraal & neutraal \\
\hline $1,4-3,1$ & laag & neutraal & neutraal & neutraal & neutraal & neutraal & neutraal & neutraal \\
\hline
\end{tabular}
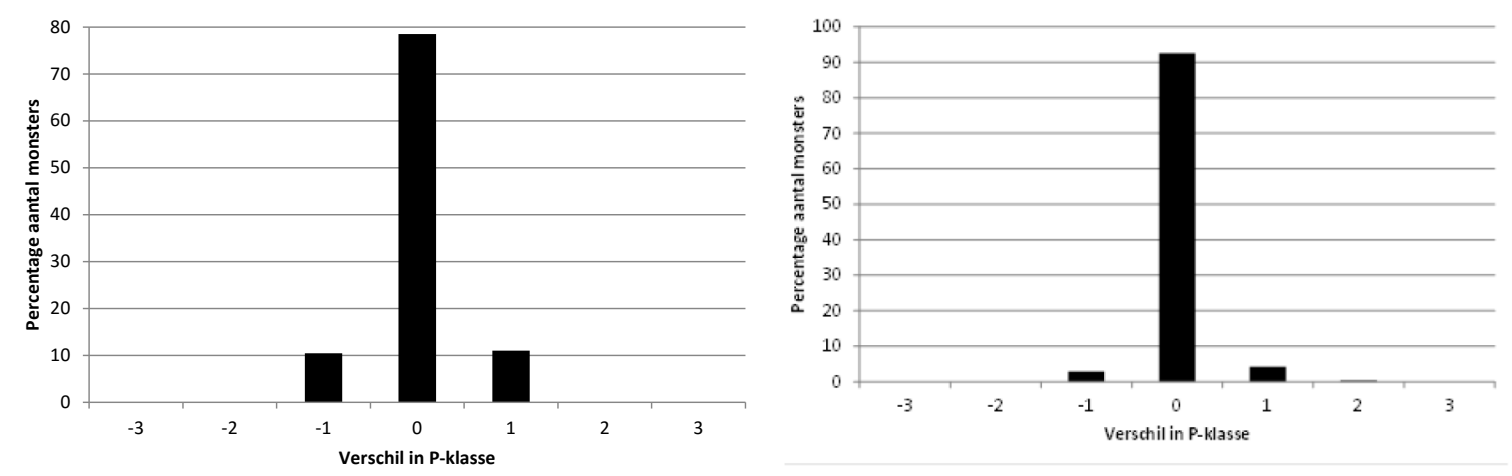

Figuur 7 Percentage van het totaal aantal monsters dat in een andere klasse van de fosfaattoestand terechtkomt bij invoering van de gecombineerde indicator met de klassengrenzen zoals voorgesteld in Tabel 16, voor bouwland (links) en grasland (rechts). Positieve waarden op de $x$ as geven weer een hogere fosfaattoestandsklasse (en dus een lagere fosfaatgebruiksnorm). 


\subsection{Voorstellen met een $5 \times 5$ matrix van klassenindeling voor de gecombineerde indicator-set met P-AL-getal en $\mathrm{P}-\mathrm{CaCl}_{2}$}

Het ministerie van Economische Zaken heeft verzocht ook voorstellen te doen voor een indeling met vijf waarderingsklassen (en dus vijf verschillende fosfaatgebruiksnormen), op basis van de gecombineerde indicator van $\mathrm{P}-\mathrm{CaCl}_{2}$ en het P-AL-getal. In Tabel 17, 18 en 19 zijn drie voorstellen uitgewerkt, voor alle landbouwgrond in Nederland (er zijn dus geen aparte tabellen gemaakt voor grasland en bouwland). Bij alle drie voorstellen is een vijfde waarderingsklasse onderscheiden, namelijk 'zeer hoog'.

Bij de uitwerking van de $5 \times 5$ matrix hebben twee overwegingen een rol gespeeld: (i) vanuit bemestingsoogpunt is het van belang in de waarderingsklassen arm en laag meer onderscheid aan te brengen, omdat in die klassen een duidelijke gewasreactie op de fosfaattoestand valt te verwachten. Echter, in de waarderingsklassen arm en laag komen relatief weinig monsters voor (Tabel 4, 5 en 6). (ii) Vanuit milieukundig oogpunt is het van belang om in de waarderingsklassen neutraal en hoog meer onderscheid in gebruiksnormen aan te brengen, omdat percelen met een hoge fosfaattoestand geen bemesting nodig hebben en een relatief groot risico geven op fosfaatverliezen door uitspoeling. Met andere woorden, er zijn argumenten om het begintraject, het eindtraject en het gehele traject (als tussenvorm) 'uit te rekken'. In Tabel 17 is het eindtraject uitgerekt, in Tabel 18 zijn de klassengrenzen voor $\mathrm{P}-\mathrm{CaCl}_{2}$ genormaliseerd op hele getallen en die van het P-AL-getal op eenheden van 10 voor het gehele traject. In Tabel 19 zijn de klassengrenzen voor $\mathrm{P}-\mathrm{CaCl}_{2}$ genormaliseerd op hele getallen, e die van het P-AL-getal zijn zoals in Tabel 17.

\section{Tabel 17}

Voorstel voor een indeling met klassen voor de waardering van de fosfaattoestand van landbouwgrond (grasland en bouwland), waarbij de bovenste twee klassen in het oorspronkelijke voorstel zijn opgesplitst in drie klassen. Percentage van het aantal monsters op bouwland dat in een bepaalde klasse valt, is weergegeven. Bron: Eurofins-databestand.

\begin{tabular}{|c|c|c|c|c|c|c|}
\hline \multirow{2}{*}{$\begin{array}{l}\mathrm{P}-\mathrm{CaCl}_{2}^{-} \\
\text {SFA, } \\
\text { mg P kg-1 }\end{array}$} & \multicolumn{5}{|c|}{$\begin{array}{l}\text { Percentage monsters (\%) per fosfaattoestandsklasse, uitgedrukt in } \\
\qquad \text { P-AL-getal, } \mathrm{mg} \mathrm{P}_{2} \mathrm{O}_{5}(100 \mathrm{~g})^{-1}\end{array}$} & \multirow{2}{*}{ Totaal } \\
\hline & $<16$ & $\begin{array}{r}P-A \\
16-27\end{array}$ & $\frac{\mathrm{mg} \mathrm{P}_{2} \mathrm{O}}{27-40}$ & $40-55$ & $>55$ & \\
\hline$<0,8$ & 2 & 6 & 5 & 2 & 0 & 15 \\
\hline $0,8-1,4$ & 0 & 4 & 7 & 7 & 3 & 20 \\
\hline $1,4-2,4$ & 0 & 2 & 7 & 9 & 7 & 25 \\
\hline $2,4-3,4$ & 0 & 1 & 2 & 4 & 6 & 13 \\
\hline$>3,4$ & 0 & 1 & 3 & 5 & 17 & 26 \\
\hline Totaal & 3 & 13 & 24 & 27 & 34 & 100 \\
\hline
\end{tabular}

\section{Tabel 18}

Voorstel voor een indeling met vijf klassen voor de waardering van de fosfaattoestand van landbouwgrond (grasland en bouwland), waarbij waarden voor alle klassen zijn 'genormaliseerd' op hele getallen ( bij P-CaCl${ }_{2}$ ) en eenheden van 10 (bij P-AL-getal). Percentage van het aantal monsters op bouwland dat in een bepaalde klasse valt, is weergegeven. Bron: Eurofins-databestand.

\begin{tabular}{|c|c|c|c|c|c|c|}
\hline \multirow{2}{*}{$\begin{array}{l}\mathrm{P}-\mathrm{CaCl}_{2}^{-} \\
\mathrm{SFA}, \\
\mathrm{mg} \mathrm{P} \mathbf{k g}^{-1}\end{array}$} & \multicolumn{5}{|c|}{$\begin{array}{l}\text { Percentage monsters (\%) per fosfaattoestandsklasse, uitgedrukt in } \\
\qquad \text { P-AL-getal, } \mathrm{mg} \mathrm{P}_{2} \mathrm{O}_{5}(100 \mathrm{~g})^{-1}\end{array}$} & \multirow[b]{2}{*}{ Totaal } \\
\hline & $<20$ & $20-30$ & $30-40$ & $40-60$ & $>60$ & \\
\hline $1,0-2,0$ & 1 & 5 & 7 & 12 & 4 & 29 \\
\hline $2,0-3,0$ & 0 & 2 & 3 & 8 & 5 & 18 \\
\hline Totaal & 6 & 16 & 19 & 33 & 27 & 100 \\
\hline
\end{tabular}


Tabel 19

Voorstel voor een indeling met vijf klassen voor de waardering van de fosfaattoestand van landbouwgrond (grasland en bouwland), waarbij de waarden voor de $\mathrm{P}$ - $\mathrm{CaCl}_{2}-\mathrm{klassen}$ zijn 'genormaliseerd' op hele getallen. Percentage van het aantal monsters op bouwland dat in een bepaalde klasse valt, is weergegeven. Bron: Eurofins-databestand.

\begin{tabular}{|c|c|c|c|c|c|c|}
\hline \multirow{2}{*}{$\begin{array}{l}\mathrm{P}-\mathrm{CaCl}_{2}^{-} \\
\text {SFA, } \\
\text { mg P kg }\end{array}$} & \multicolumn{5}{|c|}{$\begin{array}{l}\text { Percentage monsters ( } \%) \text { per fosfaattoestandsklasse, uitgedrukt in } \\
\text { P-AL-getal, } \mathrm{mg} \mathrm{P}_{2} \mathrm{O}_{5}(100 \mathrm{~g})^{-1}\end{array}$} & \multirow{2}{*}{ Totaal } \\
\hline & $<16$ & $\frac{P-A}{16-27}$ & $\frac{\mathrm{mg} \mathrm{P}_{2} \mathrm{O}}{27-40}$ & $40-55$ & $>55$ & \\
\hline$<1,0$ & 2 & 8 & 7 & 4 & 1 & 22 \\
\hline $1,0-2,0$ & 0 & 3 & 9 & 10 & 6 & 29 \\
\hline $2,0-3,0$ & 0 & 1 & 4 & 6 & 7 & 18 \\
\hline $3,0-4,0$ & 0 & 0 & 2 & 3 & 5 & 10 \\
\hline$>4,0$ & 0 & 1 & 2 & 4 & 15 & 21 \\
\hline Totaal & 3 & 13 & 24 & 27 & 34 & 100 \\
\hline
\end{tabular}

Effecten van het anders begrenzen van de waarderingsklassen op het aantal monsters per klasse zijn relatief groot. Gaande van Tabel 17 naar Tabel 19 en dan naar Tabel 18 neemt het aantal monsters in de waarderingsklasse arm toe en die in de klassen (zeer) hoog af.

In de literatuur zijn ook voorstellen gedaan om de fosfaattoestand te beschrijven op basis van $\mathrm{P}-\mathrm{CaCl}_{2}$ en de zogenoemde buffercapaciteit, de verhouding tussen $\mathrm{P}-\mathrm{AL}$-getal en $\mathrm{P}-\mathrm{CaCl}_{2}$. In onderhavige studie is niet gekozen voor een gecombineerde indicator op basis van $\mathrm{P}-\mathrm{CaCl}_{2}$ en $\mathrm{P}-\mathrm{AL}-\mathrm{getal} / \mathrm{P}-\mathrm{CaCl}_{2}$, omdat deze indicatoren niet onafhankelijk zijn. De voorkeur wordt gegeven aan een onafhankelijke combinatie van twee indicatoren, omdat dit wetenschappelijk gezien juist is. Bij een keuze voor een combinatie van $\mathrm{P}-\mathrm{CaCl}_{2}$ en buffercapaciteit zijn de twee indicatoren met elkaar verstrengeld.

Overigens kan de buffercapaciteit ook uit onafhankelijke indicatoren $\mathrm{P}-\mathrm{CaCl}_{2}$ en het P-AL-getal in Tabel 17, 18 en 19 (en andere tabellen) worden afgeleid door denkbeeldige lijnen (iso-lijnen) te trekken vanuit de oorsprong (linkerbovenhoek) naar (rechts) beneden. De waarderingsklassen voor de fosfaattoestand in de rechterbovenhoek hebben een hoge buffercapaciteit en die in de linkeronderhoek een kleine.

\subsection{Klassenindeling voor een gecombineerde indicator-set met $\mathrm{P}-\mathrm{CaCl}_{2}$, oxalaat-extraheerbaar fosfaat (P-ox) en fosfaatverzadigingsgraad (FVG)}

In een eerder advies van de CDM (CDM, 2015) is geadviseerd over een gecombineerde indicator voor de fosfaattoestand op basis van $\mathrm{P}-\mathrm{CaCl}_{2}$ en oxalaat-extraheerbaar fosfaat ( $\mathrm{P}$-ox). De laatstgenoemde parameter is een capaciteitsindicator voor de fosfaattoestand, vergelijkbaar met het P-AL-getal (Ehlert et al., 2014). In combinatie met oxalaat-extraheerbaar ijzer (Fe-ox) en aluminium (Al-ox) bepaalt Pox de fosfaatverzadigingsgraad (FVG) van de bodem en dat is een indicator voor het risico van fosfaatuitspoeling naar de ondergrond.

In deze paragraaf worden de resultaten beschreven van de analyses van een gecombineerde indicator op basis van $\mathrm{P}-\mathrm{CaCl}_{2}$ en $\mathrm{P}$-ox en op basis van $\mathrm{P}-\mathrm{CaCl}_{2}$ en $\mathrm{FVG}$. Daarbij is gebruikgemaakt van de Eurofins-database en zijn P-ox en FVG statistisch afgeleid uit het P-AL-getal via lineaire regressieanalyse. Verder is $\mathrm{P}-\mathrm{CaCl}_{2}$ afgeleid uit het $\mathrm{Pw}$-getal, zoals aangegeven in hoofdstuk 3.1.

Het model $P$-ox $=c+P$-AL-getal $+[F e-o x+A l-o x]+p H+$ organische stofgehalte + lutumgehalte verklaart $72 \%$ van de variantie in de database. Vooral het fosfaatbindend vermogen [Fe-ox $+\mathrm{Al}-\mathrm{ox}]$ levert een grote bijdrage aan de verklaring van de variantie. Dit model heeft als nadeel dat veel bodemparameters moeten worden gemeten indien de P-ox-indicator wordt afgeleid uit (gerelateerd aan) het P-AL-getal. Dat maakt introductie van de P-ox-indicator in de praktijk relatief duur, tenzij al deze parameters snel via NIRS gemeten kunnen worden. Het alternatief is dat P-ox direct wordt gekalibreerd aan resultaten van bemestingsproeven. In dat laatste geval volstaat een bepaling van 
P-ox. De kalibratie van Pox aan resultaten van bemestingsproeven ligt echter buiten de scope van de studie die in dit rapport wordt besproken.

De relaties tussen P-ox en het P-AL-getal en tussen FVG en het P-AL-getal zijn grondsoortafhankelijk (Tabel 20), maar beschrijven slechts een gering deel van de totale variantie in de database (de correlatiecoëfficiënten zijn relatief laag). De correlatiecoëfficiënten voor de relaties tussen P-ox en het P-AL-getal en tussen FVG en het P-AL-getal zijn nog lager indien geen onderscheid tussen grondsoorten wordt gemaakt (Tabel 21). Deze geringe correlatie impliceert dat andere factoren een groot effect hebben op de relatie tussen Pox en het P-AL-getal.

\section{Tabel 20}

Coëfficiënten en standaardafwijkingen van de statistische relaties tussen $P$-ox en $P$-AL-getal, en tussen FVG en P-AL-getal per landgebruik. Resultaten op basis van de analyse van de Eurofins-database.

\begin{tabular}{|c|c|c|c|c|c|c|c|c|c|c|c|c|}
\hline \multirow[t]{2}{*}{ Model } & \multirow[t]{2}{*}{$\begin{array}{l}\text { Land- } \\
\text { gebruik }\end{array}$} & \multirow[t]{2}{*}{$\mathbf{R}^{2}$} & \multicolumn{5}{|c|}{$\begin{array}{l}\text { Schattingen van de } \\
\text { regressiecoëfficiënten }\end{array}$} & \multicolumn{5}{|c|}{$\begin{array}{c}\text { Standaardafwijking van de } \\
\text { regressiecoëfficiënten }\end{array}$} \\
\hline & & & \multicolumn{4}{|c|}{ c } & a & \multicolumn{4}{|c|}{ c } & a \\
\hline \multirow{2}{*}{$\begin{array}{l}\mathrm{P}-\mathrm{ox}=\mathrm{c}+ \\
\mathrm{a} * \mathrm{PAL}\end{array}$} & Bouwland & 14,5 & 93,6 & 83,1 & 81,0 & 180,9 & 0,48 & 0,620 & 0,511 & 1,541 & 2,605 & 0,009 \\
\hline & Grasland & 41,3 & 102,1 & 149,7 & 132,0 & 247,7 & 0,39 & 0,788 & 0,790 & 2,671 & 1,065 & 0,015 \\
\hline \multirow{3}{*}{$\begin{array}{l}\text { FVG }=\mathrm{c}+ \\
\text { a*PAL }\end{array}$} & Bouwland & 1,6 & 42,0 & 29,2 & 42,1 & 19,0 & 0,21 & 1,064 & 0,878 & 2,647 & 4,475 & 0,016 \\
\hline & Grasland & 28,5 & 36,4 & 22,9 & 24,8 & 17,7 & 0,22 & 0,222 & 0,222 & 0,751 & 0,299 & 0,004 \\
\hline & $B+G$ & 3,8 & 37,7 & 25,3 & 34,4 & 17,0 & 0,24 & 0,509 & 0,470 & 1,49 & 0,899 & 0,008 \\
\hline $\begin{array}{l}\log (F V G)=c+ \\
a * \log (P A L)\end{array}$ & $B+G$ & 33,6 & 1,06 & 0,94 & 0,89 & 0,84 & 0,36 & 0,006 & 0,002 & 0,005 & 0,003 & 0,003 \\
\hline
\end{tabular}

\section{Tabel 21}

Coëfficiënten en standaardafwijkingen van de statistische relaties tussen $P$-ox en P-AL-getal, en tussen FVG en P-AL-getal per landgebruik, zonder onderscheid te maken tussen bodemtypen. Resultaten op basis van de analyse van de Eurofins-database.

\begin{tabular}{|c|c|c|c|c|c|c|}
\hline \multirow[t]{2}{*}{ Model } & \multirow[t]{2}{*}{$\begin{array}{l}\text { Land- } \\
\text { gebruik }\end{array}$} & \multirow[t]{2}{*}{$\mathbf{R}^{2}$} & \multicolumn{2}{|c|}{$\begin{array}{l}\text { Schattingen van de } \\
\text { regressiecoëfficiënten }\end{array}$} & \multicolumn{2}{|c|}{$\begin{array}{l}\text { Standaardafwijking van de } \\
\text { regressiecoëfficiënten }\end{array}$} \\
\hline & & & c & a & c & a \\
\hline \multirow{2}{*}{$\mathrm{P}-\mathrm{ox}=\mathrm{c}+\mathrm{a} * \mathrm{PAL}$} & Grasland & 0,0 & 144,4 & 0,05 & 0,913 & 0,019 \\
\hline & $B+G$ & 0,3 & 125,6 & 0,13 & 0,564 & 0,010 \\
\hline \multirow{2}{*}{$F V G=c+a * P A L$} & Grasland & 12,3 & 28,5 & 0,28 & 0,218 & 0,0045 \\
\hline & $B+G$ & 2 & 31,0 & 0,28 & 0,462 & 0,008 \\
\hline \multirow[t]{2}{*}{$\log (F V G)=c+a * \log (P A L)$} & Bouwland & 18,1 & 0,893 & 0,441 & 0,010 & 0,006 \\
\hline & Grasland & 20,7 & 0,955 & 0,390 & 0,007 & 0,005 \\
\hline
\end{tabular}

Ook de relaties tussen fosfaatverzadigingsgraad (FVG) en het P-AL-getal zijn zwak (Tabel 20). Het is niet duidelijk waarom de relaties beter zijn voor grasland dan voor bouwland. De indicatoren FVG en $\mathrm{P}$-ox zijn niet onafhankelijk, want FVG is de ratio van P-ox en fosfaatbindend vermogen (FVG = $\mathrm{P}-\mathrm{ox} /(\mathrm{Fe}-\mathrm{ox}+\mathrm{Al}-\mathrm{ox})$, in \%.

Op basis van de statistische relaties tussen P-ox en het P-AL-getal en tussen FVG en het P-AL-getal (zonder onderscheid tussen grondsoorten) zijn voorstellen gedaan voor klassengrenzen voor de gecombineerde indicatoren $\mathrm{P}-\mathrm{CaCl}_{2}$ en $\mathrm{P}$-ox voor bouwland (Tabel 22) en grasland (Tabel 23) en de gecombineerde indicatoren P-CaCl 2 en FVG voor bouwland (Tabel 24) en grasland (Tabel 25). Hierbij zijn de modellen gebruikt die zijn afgeleid van afzonderlijke sets voor bouwland en grasland. 
Opvallend is dat de klassengrenzen fors verschillen tussen bouwland en grasland, zowel bij P-ox als FVG. Verder valt op dat er relatief veel monsters terecht zijn gekomen in de laagste en hoogste klassen van P-ox. Toepassing van dit concept en deze klassengrenzen leidt dus tot een forse verschuiving in de fosfaatplaatsingsruimte. Deze gecombineerde indicators worden derhalve niet aanbevolen.

Hoewel de relaties tussen P-ox en het P-AL-getal en tussen FVG en het P-AL-getal teleurstellend zijn wat betreft verklaarde variantie, kan niet worden uitgesloten dat bij een onafhankelijke toetsing van de relaties tussen P-ox en het P-AL-getal enerzijds en de reactie van het gewas op fosfaatbemesting en fosfaattoestand anderzijds wel goede verbanden worden gevonden. Dit vergt echter nadere studie.

\section{Tabel 22}

Voorstel voor klassengrenzen van de fosfaattoestand van bouwland met een gecombineerde indicator ( $P$-CaCl${ }_{2}$-SFA als intensiteitsindicator en $\mathrm{P}$-ox als capaciteitsindicator). De $\mathrm{P}-\mathrm{CaCl}_{2}$ grenswaarden zijn afgeleid van de grenswaarden voor Pw-getal in Tabel 1 en de relatie in Tabel 3. De P-ox grenswaarden zijn afgeleid van de grenswaarden van het $P$-AL-getal in Tabel 1 en de relaties in Tabel 21 . Voor iedere gecombineerde klasse is het percentage van het totaal aantal monsters op bouwland weergegeven op basis van data Eurofins.

\begin{tabular}{|c|c|c|c|c|}
\hline \multirow[t]{2}{*}{$\begin{array}{l}\mathrm{P}-\mathrm{CaCl}_{2}-\mathrm{SFA} \text {, } \\
\text { mg P kg }\end{array}$} & \multicolumn{4}{|c|}{$\begin{array}{l}\text { Percentage monsters op bouwland per fosfaattoestandsklasse, } \\
\text { uitgedrukt in } \mathrm{P}-\mathrm{ox}, \mathrm{mg} \mathrm{P} \mathrm{kg}^{-1}\end{array}$} \\
\hline & $<97$ & $97-103$ & $103-114$ & $>114$ \\
\hline $0,8-1,4$ & 5 & 1 & 2 & 12 \\
\hline $1,4-3,1$ & 8 & 2 & 3 & 18 \\
\hline
\end{tabular}

\section{Tabel 23}

Voorstel voor klassengrenzen van de fosfaattoestand van grasland met een gecombineerde indicator ( $P$ - $\mathrm{CaCl}_{2}$-SFA als intensiteitsindicator en $\mathrm{P}$-ox als capaciteitsindicator). De $\mathrm{P}$ - $\mathrm{CaCl}_{2}$ grenswaarden zijn afgeleid van de grenswaarden voor Pw-getal in Tabel 1, de P-ox grenswaarden zijn afgeleid van de grenswaarden van het P-AL-getal in Tabel 1 en de relaties in Tabel 21 . Voor iedere gecombineerde klasse is het percentage van het totaal aantal monsters op grasland weergegeven, op basis van data Eurofins.

\begin{tabular}{|c|c|c|c|c|}
\hline \multirow[t]{2}{*}{$\begin{array}{l}\mathrm{P}-\mathrm{CaCl}_{2}-\mathrm{SFA} \text {, } \\
\mathrm{mg} \mathrm{P} \mathrm{kg}\end{array}$} & \multicolumn{4}{|c|}{$\begin{array}{l}\text { Percentage monsters op grasland per fosfaattoestandsklasse, } \\
\text { uitgedrukt in } \mathbf{P}-\mathrm{ox}, \mathrm{mg} \mathrm{P} \mathrm{kg}\end{array}$} \\
\hline & $<145$ & $145-146$ & $146-147$ & $>147$ \\
\hline $0,8-1,4$ & 7 & 1 & 2 & 15 \\
\hline $1,4-3,1$ & 9 & 2 & 3 & 19 \\
\hline
\end{tabular}


Tabel 24

Voorstel voor klassengrenzen van de fosfaattoestand van bouwland met een gecombineerde indicator ( $\mathrm{P}-\mathrm{CaCl}_{2}-\mathrm{SFA}$ als intensiteitsindicator en $\mathrm{FVG}$ als capaciteitsindicator). De $\mathrm{P}$ - $\mathrm{CaCl}_{2}$-grenswaarden zijn afgeleid van de grenswaarden voor Pw-getal in Tabel 1, de FVG-grenswaarden zijn afgeleid van de grenswaarden van het P-AL-getal in Tabel 1. Voor iedere gecombineerde klasse is het percentage van het totaal aantal monsters op bouwland weergegeven op basis van data Eurofins.

\begin{tabular}{|c|c|c|c|c|}
\hline \multirow[t]{2}{*}{$\begin{array}{l}\mathrm{P}-\mathrm{CaCl}_{2}-\mathrm{SFA} \text {, } \\
\mathrm{mg} \mathrm{P} \mathrm{kg}\end{array}$} & \multicolumn{4}{|c|}{$\begin{array}{l}\text { Percentage monsters op bouwland per fosfaattoestandsklasse, } \\
\text { uitgedrukt in FVG, \% }\end{array}$} \\
\hline & $<27$ & $27-33$ & $33-44$ & $>44$ \\
\hline$<0,8$ & 4 & 3 & 3 & 1 \\
\hline $0,8-1,4$ & 3 & 4 & 7 & 6 \\
\hline $1,4-3,1$ & 2 & 3 & 9 & 17 \\
\hline$>3,1$ & 1 & 2 & 6 & 28 \\
\hline
\end{tabular}

\section{Tabel 25}

Voorstel voor klassengrenzen van de fosfaattoestand van grasland met een gecombineerde indicator ( $\mathrm{P}$ - $\mathrm{CaCl}_{2}$-SFA als intensiteitsindicator en FVG als capaciteitsindicator). De $\mathrm{P}$-CaCl${ }_{2}$-grenswaarden zijn afgeleid van de grenswaarden voor Pw-getal in Tabel 1, de FVG-grenswaarden zijn afgeleid van de grenswaarden van het P-AL-getal in Tabel 1. Voor iedere gecombineerde klasse is het percentage van het totaal aantal monsters op grasland weergegeven op basis van data Eurofins.

\begin{tabular}{lcccc}
$\mathrm{P}-\mathrm{CaCl}_{2}-\mathrm{SFA}$, & \multicolumn{4}{c}{ Percentage monsters op grasland per fosfaattoestandsklasse, } \\
$\mathrm{mg} \mathrm{P} \mathrm{kg}$ & \multicolumn{4}{c}{ uitgedrukt in FVG, \% } \\
\cline { 2 - 5 } & $<27$ & $27-33$ & $33-41$ & $>41$ \\
0,8 & 9 & 3 & 4 & 2 \\
$1,4-3,1$ & 7 & 5 & 7 & 7 \\
$>3,1$ & 5 & 5 & 9 & 14 \\
\hline
\end{tabular}

De waarden van FVG zijn voor alle klassen hoger dan 25\%. Dit suggereert dat de fosfaatconcentratie in de bodemoplossing van de bouwvoor die uitspoelt naar de ondergrond hoger is dan 0,15 $\mathrm{mg} \mathrm{PO}_{4}-\mathrm{P}$ per liter. Deze waarde wordt in Nederland soms gehanteerd als grenswaarde voor de eutrofiering van oppervlakte water. 


\section{$4 \quad$ Discussie en Conclusies}

In deze studie zijn voorstellen ontwikkeld voor numerieke grenswaarden van de waarderingsklassen van de fosfaattoestand van de bodem, ten behoeve van de afleiding van fosfaatgebruiksnormen. Deze voorstellen zijn gedaan, omdat er voornemens zijn de indicator voor bouwland (Pw-getal) en die voor grasland ( $\mathrm{P}-\mathrm{AL}$-getal) in het huidige stelsel te vervangen door een gecombineerde indicator, d.w.z. een intensiteitsparameter $\left(\mathrm{P}-\mathrm{CaCL}_{2}\right)$ en een capaciteitsparameter ( $\mathrm{P}-\mathrm{AL}$-getal). In de praktijk van de bemestingsadvisering wordt een gecombineerde indicator van $\mathrm{P}-\mathrm{CaCl}_{2}$ en een $\mathrm{P}-\mathrm{AL}$-getal reeds toegepast voor grasland en snijmais. Er zijn plannen om die ook toe te passen in de akker-en tuinbouw.

Voor de gecombineerde indicator van $\mathrm{P}-\mathrm{CaCl}_{2}$ en een $\mathrm{P}-\mathrm{AL}$-getal zijn zes voorstellen uitgewerkt, drie voorstellen met vier waarderingsklassen en drie voorstellen met vijf waarderingsklassen. De grenzen voor de waarderingsklassen voor $\mathrm{P}-\mathrm{CaCl}_{2}$ zijn statistisch afgeleid van het $\mathrm{Pw}$-getal in het huidige stelsel, terwijl die van het P-AL-getal zijn gekopieerd uit het huidige stelsel. Bij enkele voorstellen zijn de klassengrenzen aangepast om meer of minder diagnostische waarde toe te kennen aan $\mathrm{P}-\mathrm{CaCl}_{2}$ ten opzichte van het P-AL-getal. Het aantal gedane voorstellen is niet uitputtend.

In Tabel 26 wordt een overzicht gegeven van de percentages grondmonsters van het Eurofins-bestand per waarderingsklasse van de fosfaattoestand. In het stelsel met vier waarderingsklassen worden arm, laag, neutraal en hoog onderscheiden, in het stelsel met vijf waarderingsklassen worden arm, laag, neutraal, hoog en zeer hoog onderscheiden (voor het laatstgenoemde stelsel zijn nog geen fosfaatgebruiksnormen beschikbaar). De verdeling van het aantal monsters verschilt per waarderingsklasse en per variant. Het percentage monsters is een globale maat voor het areaal landbouwgrond in Nederland per waarderingsklasse ${ }^{4}$.

\section{Tabel 26}

Percentage grondmonsters per waarderingsklasse van de fosfaattoestand en per variant. De varianten zijn beschreven in hoofdstuk 3. Voor iedere waarderingsklasse is het percentage van het totaal aantal monsters op landbouwgrond (grasland + bouwland) weergegeven op basis van de Eurofins-database.

\begin{tabular}{|c|c|c|c|c|c|}
\hline \multirow[t]{2}{*}{ Varianten } & \multicolumn{5}{|c|}{ Waarderingsklasse fosfaattoestand } \\
\hline & arm & laag & neutraal & hoog & zeer hoog \\
\hline Eerdere CDM-voorstel & 8 & 10 & 39 & 43 & \\
\hline P-AL-getal meer waarde dan $\mathrm{P}-\mathrm{CaCl}_{2}$ & 2 & 16 & 39 & 43 & \\
\hline $5 \times 5$ matrix variant a & 8 & 13 & 22 & 29 & 28 \\
\hline $5 \times 5$ matrix variant $c$ & 10 & 15 & 24 & 27 & 24 \\
\hline
\end{tabular}

\footnotetext{
4 Er wordt hierbij aangenomen dat de Eurofins-database representatief is voor de beschrijving van de variatie in fosfaattoestand in Nederland. In hoofdstuk 3.2 is aangegeven dat het Eurofins-databestand verschilt met dat van RVO.nl en dat beide bestanden niet tot stand zijn gekomen via representatieve steekproeven.
} 


\subsection{Implicaties voorgestelde klassengrenzen voor gewasopbrengsten}

Fosfaat is een essentiële voedingsstof voor planten. De gewasopbrengst en de fosfaatopname in het gewas worden bepaald door de fosfaattoestand van de bodem en de fosfaatbemesting (en natuurlijk door weersomstandigheden, de beschikbaarheid van water en andere nutriënten, ziekten en plagen, en management). Bij een hoge fosfaattoestand heeft fosfaatbemesting geen effect, bij een lage fosfaattoestand wordt door een ruime fosfaatbemesting niet de economisch optimale gewasopbrengst gerealiseerd. Een te lage fosfaattoestand moet worden voorkomen om opbrengstderving te voorkomen. De grenswaarde voor een 'te-lage' fosfaattoestand verschilt per gewas. In het huidige stelsel liggen die grenswaarden bij een Pw-getal van $<25$ en een P-AL-getal $<16$ (waarderingsklasse 'arm'), waarvoor een specifiek bemonsteringsprotocol van toepassing is, en een relatief hoge fosfaatgebruiksnorm geldt (hoger dan de fosfaatonttrekking via het geoogste gewas). Die grenzen zijn in de voorstellen van deze studie overgenomen (na omrekening). In het eerdere CDM-voorstel (CDM, 2015) is de waarderingsklasse 'arm' uitgebreid door ook de nabijgelegen klasse van een van de twee indicatoren erbij te trekken. Het argument daarvoor is dat het risico op opbrengstderving door fosfaatgebrek beperkt dient te worden. In het eerdere CDM-voorstel (CDM, 2015) vallen relatief veel grondmonsters in de waarderingsklasse 'arm', vergeleken met de huidige situatie (volgens Tabel B7 in Bijlage 5 valt minder dan $5 \%$ van het bouwland- en graslandareaal in de klasse van fosfaat-fixerende gronden).

Uit de statistische analyses blijkt dat de verschillen tussen bouwland en grasland in de variantie van de relatie tussen $\mathrm{P}-\mathrm{CaCl}_{2}$ en $\mathrm{Pw}$-getal miniem zijn (Tabel 3). Dat pleit er voor om voor bouwland en grasland een uniforme waardering van de fosfaattoestandsklassen toe te passen. Daarbij wordt impliciet aangenomen dat de waardering die aan het P-AL-getal wordt gegeven voor grasland ook van toepassing kan zijn op bouwland. Uit Figuur 5 blijkt echter dat voornoemde aanname niet juist is. De voorgestelde waarderingsklassen in het eerdere CDM-voorstel (CDM, 2015) trekken de waardering van de fosfaattoestand van circa $40 \%$ van de bouwlandpercelen een klasse naar beneden. Hier blijkt de waardering van het P-AL-getal voor grasland dus te verschillen van de waardering van het P-AL-getal voor bouwland; dit wordt vooral veroorzaakt door verschuiving tussen de klassen neutraal en hoog, door de invloed van het P-AL-getal.

Om verschuiving van grondmonsters naar andere klassen zo veel mogelijk te voorkomen, bij de overgang van de huidige indicatoren (Pw-getal voor bouwland en P-AL-getal voor grasland) naar de gecombineerde indicator ( $\mathrm{P}-\mathrm{CaCl}_{2}$ en $\mathrm{P}-\mathrm{AL}$-getal voor bouwland en grasland) is in Tabel 16 een voorstel uitgewerkt waarbij aan de fosfaattoestand van grasland en bouwland een verschillende waardering is gegeven. Toepassing van dit waarderingsschema leidt tot een heel geringe (en evenredige) verschuiving van grondmonsters naar andere klassen. Het mogelijke nadeel van dit schema is dat de waardering van de fosfaattoestand voor grasland en bouwland verschilt voor veel combinaties van $\mathrm{P}-\mathrm{CaCl}_{2}$ en het P-AL-getal.

Een stelsel met vijf waarderingsklassen kan op verschillende wijzen worden ingericht. In de drie voorstellen die zijn gedaan, is de verdeling van het aantal monsters over de waarderingsklassen gelijkmatiger geworden, de monsters in de klasse 'hoog' zijn verspreid over 'hoog' en 'zeer hoog'. Voor de klasse 'zeer hoog' is geen fosfaatgebruiksnorm bekend, maar het ligt in de verwachting dat die lager is dan die voor de klasse 'hoog'. Er zijn geen voorstellen gedaan waarin meer of minder diagnostische waarde wordt toegekend aan $\mathrm{P}-\mathrm{CaCl}_{2}$ dan aan het P-AL-getal, maar dat is nog wel mogelijk.

Samenvattend: omdat de voorstellen voor de klassengrenzen van $\mathrm{P}-\mathrm{CaCl}_{2}$ zijn afgeleid uit de huidige klassengrenzen van het Pw-getal, en de gecombineerde indicator het perspectief biedt dat de fosfaattoestand van de bodem gevoeliger wordt vastgelegd, kan de conclusie worden getrokken dat het risico op derving van gewasopbrengst door fosfaatgebrek vergelijkbaar of kleiner is bij toepassing van een gecombineerde indicator dan bij toepassing van het huidige stelsel gebaseerd op het Pw-getal voor bouwland en op het P-AL-getal voor grasland. 


\subsection{Implicaties voorgestelde klassengrenzen voor fosfaatverliezen}

De fosfaattoestand (bepaald via $\mathrm{P}-\mathrm{CaCl}_{2}$ en/of $\mathrm{P}-\mathrm{AL}$-getal) is een maat voor de verwachte reactie van het gewas op fosfaatbemesting. Het verband tussen $\mathrm{P}-\mathrm{CaCl}_{2}$ en/of $\mathrm{P}-\mathrm{AL}$-getal en de grootte van de fosfaatverliezen naar ondergrond, grondwater en oppervlaktewater is niet bekend, want niet onderzocht. Te verwachten is dat de verbanden sterk zullen verschillen tussen grondsoorten en hydrologische situaties. In het algemeen geldt hoe hoger de fosfaattoestand, hoe hoger het risico van fosfaatverliezen door uitspoeling en afspoeling, maar dit verband is niet empirisch onderbouwd voor het $\mathrm{P}-\mathrm{CaCl}_{2}$ en het $\mathrm{P}$-AL-getal. In de gedane voorstellen met de gecombineerde indicator zijn de klassengrenzen voor $\mathrm{P}-\mathrm{CaCl}_{2}$ en het $\mathrm{P}$-AL-getal afgeleid van de huidige klassengrenzen van het $\mathrm{PW}$ getal voor bouwland en het P-AL-getal voor grasland. Dit impliceert dat de gedane voorstellen eenzelfde basis hebben als het huidige systeem van het Pw-getal voor bouwland en het P-AL-getal voor grasland. Daarom is de verwachting dat introductie van de gecombineerde indicator niet tot een verandering in het risico van fosfaatverliezen leidt.

\subsection{Implicaties voorgestelde klassengrenzen voor fosfaatgebruiksruimte}

De fosfaatgebruiksruimte in de Nederlandse landbouw wordt bepaald door (i) het totale areaal grasland en bouwland (en overige grond), (ii) de fosfaattoestandsklasse per perceel, in combinatie met de grootte van het perceel, en (iii) de fosfaatgebruiksnormen (Tabel 1). De klassengrenzen beïnvloeden de waardering van de fosfaattoestand en daardoor de totale fosfaatgebruiksruimte. De beschikbare databases geven niet de mogelijkheid om nauwkeurig uit te rekenen wat het effect is van de voorgestelde klassengrenzen op de totale fosfaatgebruiksruimte. Enige verschuivingen zullen optreden bij introductie van een gecombineerde indicator set in de praktijk. Verschuivingen treden ook op door een hernieuwde bemonstering en bepaling van de fosfaattoestand van een perceel, omdat de bodem van een perceel ruimtelijk heterogeen is en de fosfaattoestand van plaats tot plaats kan verschillen.

In Tabel 16 is een voorstel gedaan waarbij de waardering van de klassen zodanig is gekozen dat de fosfaatgebruiksruimte naar verwachting slechts heel weinig zal veranderen. Bij de voorstellen gedaan in Tabel 11, 12, 13, 14, en 15 is de verwachting dat de fosfaatgebruiksruimte op grasland ongeveer gelijk blijft en die van bouwland zal afnemen. In deze voorstellen stijgt de waardering van de fosfaattoestand van bouwland bij circa $40 \%$ van de monsters één klasse. Dit impliceert dat de fosfaatgebruiksnorm voor deze percelen met 10 à $15 \mathrm{~kg} \mathrm{P}_{2} \mathrm{O}_{5} \mathrm{~kg}$ per ha per jaar lager is geworden (zie Tabel 1). In het ongunstigste geval betekent dit een afname van de fosfaatgebruiksruimte van 5 miljoen $\mathrm{kg} \mathrm{P}_{2} \mathrm{O}_{5}$ per jaar (15 kg x 40\% x 822.000 ha; Bijlage 2). In de voorbije 25 jaren is de fosfaatgebruiksruimte in Nederland sterk afgenomen, vooral door een vermindering van de fosfaatgebruiksruimte (Figuur 8). 


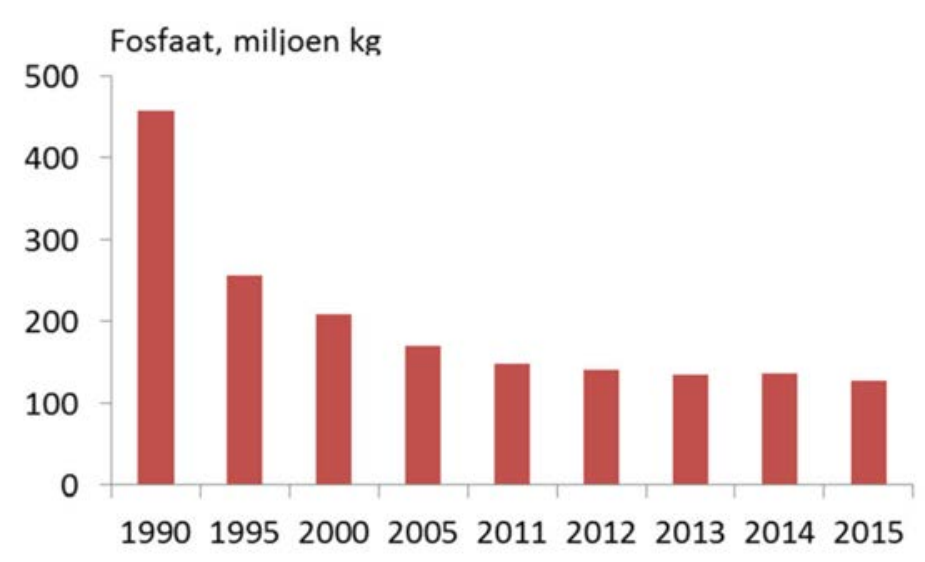

Figuur 8 Veranderingen in de fosfaatgebruiksruimte van landbouwgrond in Nederland. Bron: CBS.

\subsection{Conclusies}

De Eurofins-database bevat analysegegevens van 55.000 grondmonsters van percelen verspreid over heel Nederland. Deze database is een goede basis voor het afleiden van klassengrenzen van de gecombineerde indicator $\mathrm{P}-\mathrm{CaCl}_{2}$ en het $\mathrm{P}-\mathrm{AL}$-getal voor de fosfaattoestand van bouwland en grasland.

Via regressieanalyse zijn relaties berekend tussen meetwaarden van $\mathrm{P}-\mathrm{CaCl}_{2}$ en het $\mathrm{Pw}$-getal. Deze relaties zijn gebruikt om de klassengrenzen van het $\mathrm{PW}$-getal in het huidige stelsel om te rekenen naar waarden voor $\mathrm{P}-\mathrm{CaCl}_{2}$. Dit leidt tot een $4 \times 4$ matrix met 16 combinaties van $\mathrm{P}-\mathrm{CaCl}_{2}$ en het $\mathrm{P}$-AL-getal. Via clustering zijn deze 16 combinaties vervolgens gereduceerd tot 4 klassen: arm, laag, neutraal en hoog (gelijk aan het huidige stelsel).

Er zijn verschillende overwegingen mogelijk om de $4 \times 4$ combinaties van $\mathrm{P}-\mathrm{CaCl}_{2}$ en $\mathrm{P}$-AL-getal te clusteren tot 4 klassen voor de fosfaattoestand. Belangrijkste overweging is de verwachte reactie van gewassen op de fosfaattoestand van de bodem. Een andere overweging is dat de verandering in de fosfaatgebruiksruimte zo weinig mogelijk dient te wijzigen ten opzichte van de huidige situatie. Deze overwegingen hebben geleid tot verschillende voorstellen. Tabel 16 geeft het voorstel waarbij zoveel mogelijk aan beide overwegingen is voldaan; in dit voorstel verschilt de waardering van $\mathrm{P}-\mathrm{CaCl}_{2}$ en P-AL-getal tussen bouwland en grasland.

Op verzoek van het ministerie van Economische Zaken zijn ook drie voorstellen uitgewerkt met $5 \times 5$ combinaties van $\mathrm{P}-\mathrm{CaCl}_{2}$ en het P-AL-getal, waarbij door clustering 5 klassen voor de fosfaattoestand zijn verkregen: arm, laag, neutraal, hoog en zeer hoog. Een stelsel van 5 klassen biedt meer mogelijkheden bij de mogelijke introductie van zogenoemde equivalente maatregelen, waarbij boeren onder bepaalde voorwaarden hogere of lagere fosfaatgebruiksnormen mogen toepassen.

De analysegegevens van de database van Eurofins is ook vergeleken met een database van de Rijksdienst voor Ondernemend Nederland (RVO), die wordt gebruikt voor de bepaling van de fosfaatgebruiksruimte per perceel en bedrijf. De gemiddelde en mediane fosfaattoestand per landgebruik en per provincie volgens de Eurofins-database verschilt van die van RVO. In de Eurofinsdatabase zijn de oppervlaktes van de bemonsterde en niet-bemonsterde percelen niet bekend. Daarom kunnen de gevolgen van de voorstellen van klassengrenzen voor de fosfaatgebruiksruimte niet nauwkeurig worden berekend op basis van de Eurofins-database. 


\section{Literatuur}

Adviesbasis voor de Bemesting van Akkerbouw- en Vollegrondsgroentengewassen (2016). http://www.kennisakker.nl/kenniscentrum/handleidingen/adviesbasis-voor-de-bemesting-vanakkerbouwgewassen

Adviesbasis bemesting grasland en voedergewassen (2016). http://www.bemestingsadvies.nl/

Bussink, W., G. Doppenberg, W. van den Berg en K. van Wijk (2014). Naar een nieuw fosfaatbemestingsadvies in de akkerbouw. Nutriënten Management Instituut NMI BV.

Commissie Deskundigen Meststoffenwet (2015). Actualisering methodiek en protocol om de fosfaattoestand van de bodem vast te stellen. Wettelijke Onderzoekstaken Natuur \& Milieu, Wageningen. WOt-technical report 39. $68 \mathrm{blz}$.

Ehlert, P.A.I., Burgers, S.L.G.E, Bussink, D.W., Temminghoff, E.J.M., Erp, P.J. van, en Riemsdijk, W.H. van (2007). Deskstudie naar de mogelijkheden van het aanwijzen van fosfaatarme gronden op basis van P-PAE. Stand van zaken 2006. Alterra-rapport 1458. http://edepot.wur.nl/38112

Ehlert, P.A.I., W.J. Chardon en S.L.G.E. Burgers (2014). Fosfaattoestand en fosfaatgebruiksnorm; Betekenis van het fosfaat-bufferend vermogen van de bodem: ontwerp van een protocol. Wageningen, Alterra Wageningen UR (University \& Research centre), Alterra-rapport 2500. $104 \mathrm{blz}$.

Jordan-Meille, L., G.H. Rubæk, P.A.I. Ehlert, V. Genot, Georges Hofman UGent, K. Goulding, J. Recknagel, G. Provolo and P. Barraclough (2012). An overview of fertilizer-P recommendations in Europe: soil testing, calibration and fertilizer recommendations. Soil Use and Management 28, 419-435.

Rijksoverheid (2004). Derde Nederlandse Actieprogramma (2004-2009) inzake de Nitraatrichtlijn; 91/676/EEG.

Rijksoverheid (2009). Vierde Nederlandse Actieprogramma betreffende de Nitraatrichtlijn (20102013). Ministerie van Landbouw, Natuur en Visserij, Den Haag. https://www.rijksoverheid.nl/documenten/rapporten/2009/03/24/vierde-nederlandseactieprogramma-betreffende-de-nitraatrichtlijn-2010-2013.

Rijksoverheid (2014). 5e Nederlandse AP betreffende de Nitraatrichtlijn (2014 - 2017). https://www.rijksoverheid.nl/documenten/rapporten/2014/12/02/5e-nederlandse-ap-betreffendede-nitraatrichtlijn-2014-2017

Reijneveld JA (2013). Unravelling changes in soil fertility of agricultural land in The Netherlands. PhD thesis Wageningen University, Wageningen.

Van Erp, P.J. (2002). The potentials of multi-nutrient soil extraction with $0.01 \mathrm{M} \mathrm{CaCl} 2$ in nutrient management. PhD thesis Wageningen University, Wageningen.

Van Rotterdam-Los, A.M.D. (2010). The potential of soils to supply phosphorus and potassium. Processes and predictions. Wageningen, Proefschrift 26 februari 2010, pp 139. 


\section{Bijlage 1 Afleiding statistische relaties tussen $\mathrm{P}-\mathrm{CaCl}_{2}$ en $\mathrm{Pw}$-getal}

Uit gemaakte scatterplots blijkt dat $\mathrm{P}-\mathrm{CaCl}_{2}$ (PPAE) sterk gerelateerd is aan het Pw-getal. Het lineaire verband $\left[\mathrm{P}-\mathrm{CaCl}_{2}=\mathrm{a}+\mathrm{b} * \mathrm{Pw}\right]$ verklaart $75 \%$ van de variantie in het geval van bouwland en $82 \%$ in het geval van grasland. Het is echter ook van belang dat de residuen onafhankelijk zijn van het niveau van de voorspelling. Worden de residuen groter bij een hogere waarde van de voorspelling, dan moet er log-getransformeerd worden (Figuur B1).

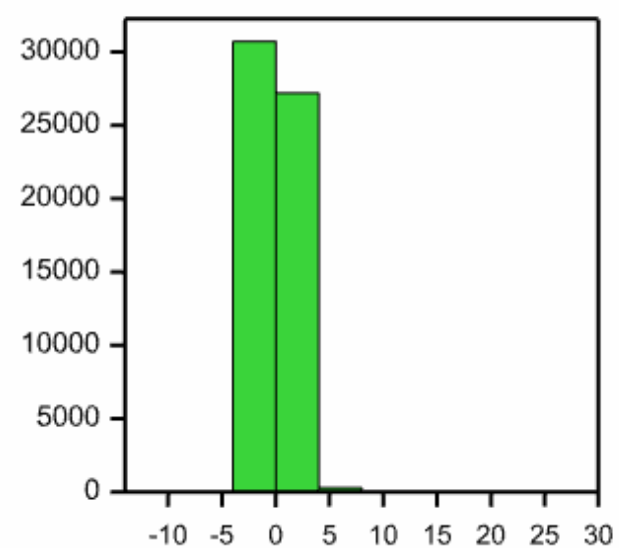

Standardized residuals

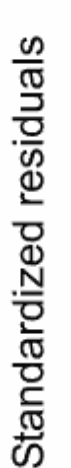

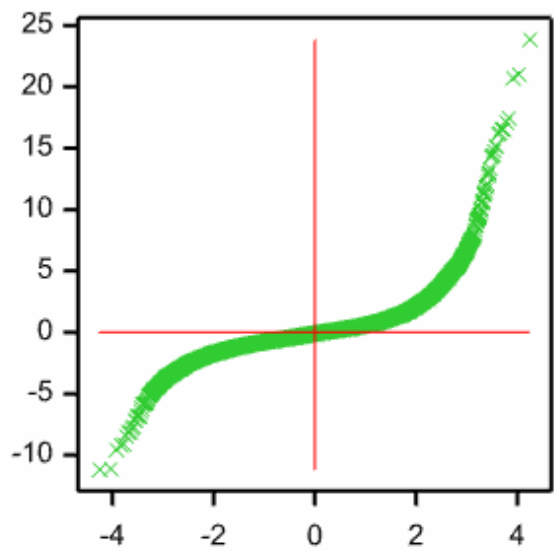

Normal plot

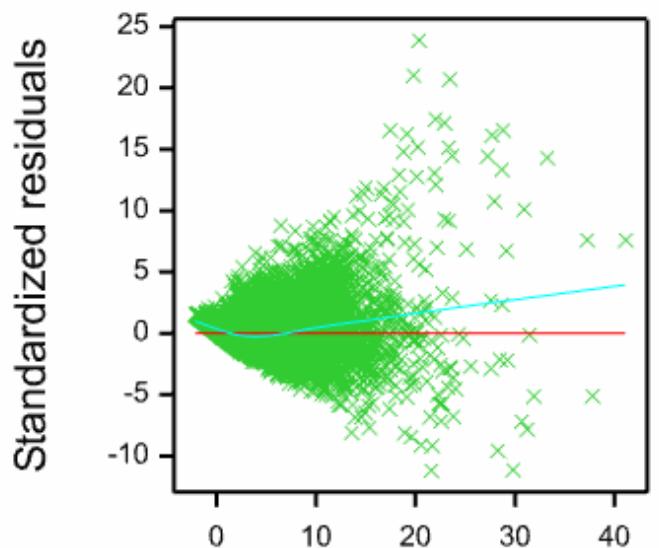

Fitted values

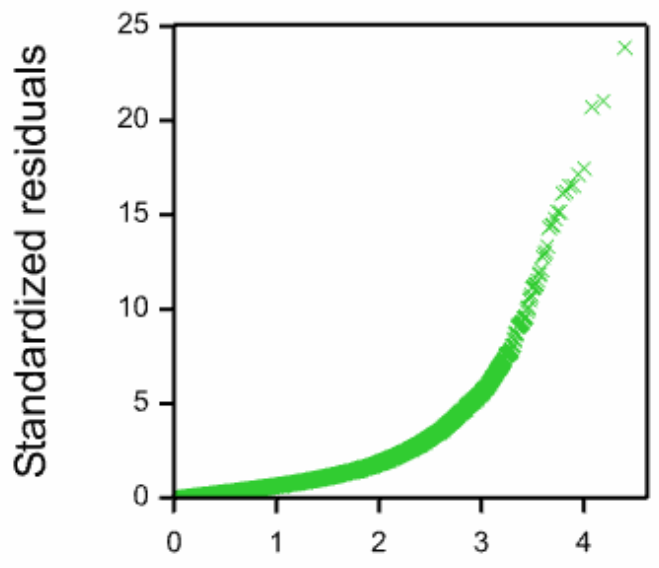

Half-Normal plot

Figuur B1 Residuenplots van het lineaire model: $P P A E=c+a * P w$

Na log-transformatie blijkt dat het niet-lineaire verband [InPPAE $=a+b * P w] 79-80 \%$ van de variantie van de relatie tussen $\mathrm{P}-\mathrm{CaCl}_{2}$ en het $\mathrm{Pw}$-getal te verklaren, maar de residuen vertonen nog steeds een patroon waarbij de kleinste residuen voorkomen bij lage en hoge waarden van de voorspelling. Een exponentieel model [InPPAE $=a+b^{*} D^{\wedge} P$ Pw] verklaart zo'n $82 \%$ van de variantie van de relatie tussen $\mathrm{P}-\mathrm{CaCl}_{2}$ en het $\mathrm{Pw}$-getal. Dit model heeft een verdeling van de residuen die acceptabel is (Figuur B2). De standaardafwijking van de voorspelling (se) is:

$$
s e=\sqrt{s^{2}} *\left(1+\frac{1}{n} *\left(\frac{(x 0-x g e m)^{2}}{\sum(x i-x g e m)^{2}}\right)\right)
$$


Hierin is $n$ het aantal waarnemingen in de database, $x 0$ de Pw-waarde waarbij een PPAE voorspeld wordt, $x i$ elke afzonderlijke getransformeerde $\mathrm{Pw}$ in de database en $x g e m$ het gemiddelde van de getransformeerde Pw's in de database. Bij zulke grote aantallen waarnemingen (20.000 tot 30.000) is de standaardafwijking gelijk aan de wortel van MSres. Het 95\%-betrouwbaarheidsinterval is gelijk aan 1.96*se. Nadat de betrouwbaarheidsintervallen berekend zijn, kan weer terug-getransformeerd worden van $\ln (\mathrm{PPAE})$ naar PPAE.

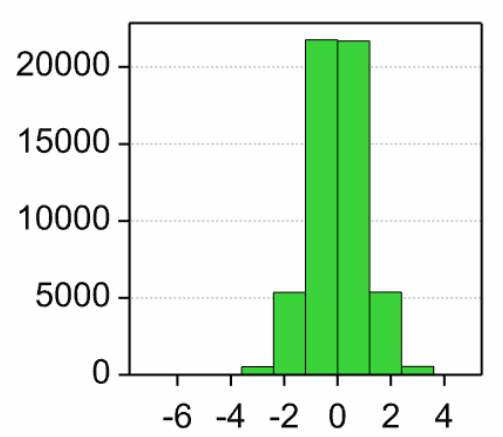

Standardized residuals

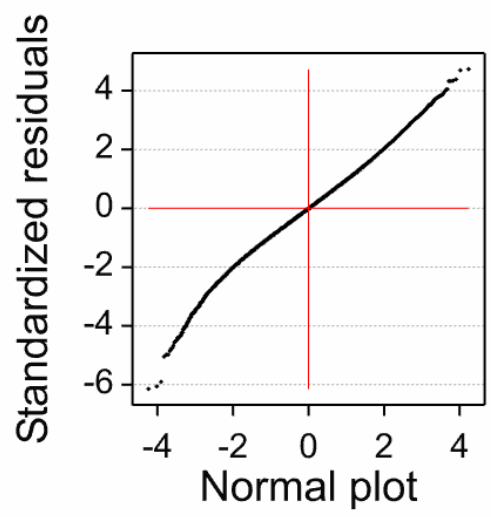

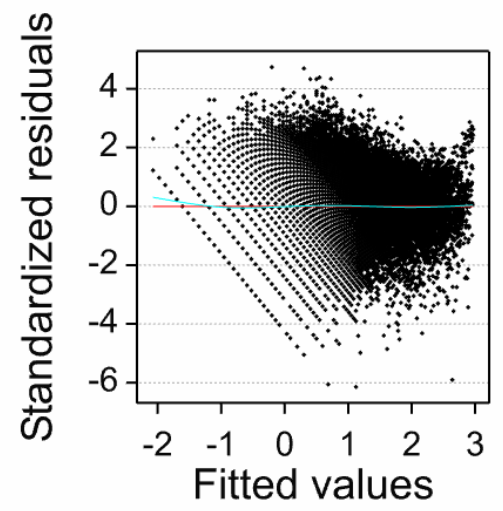

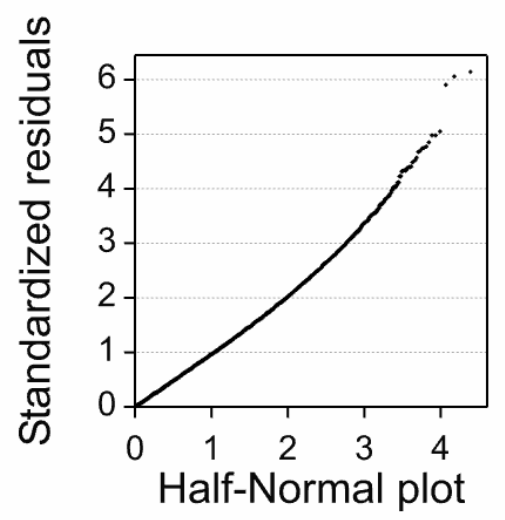

Figuur B2 Residuenplots van het exponentiele model: InPPAE $=a+b^{*} D^{\wedge} P W$

De coëfficiënten en standaardafwijking van de coëfficiënten van de relaties tussen PPAE en Pw-getal en tussen P-AL-getal en Pw-getal zijn weergegeven in Tabel B1 en B2. Een groot aantal statistische modellen is getoetst, zowel lineaire, log-getransformeerde en exponentiële modellen. Alle modellen hebben een relatief hoge verklaarde variatie. Modellen hadden een iets hogere verklaarde variantie (1 à $2 \%$ ) indien ook het lutumgehalte, $\mathrm{pH}$ en organische stofgehalte als verklarende variabelen waren opgenomen (niet getoond). De correlatiecoëfficiënt van het verband tussen PPAE en het Pw-getal en tussen P-AL-getal en het Pw-getal worden niet of nauwelijks beïnvloed door $\mathrm{pH}$ en lutumgehalte en organische stofgehalte. Daarom zijn de variabelen $\mathrm{pH}$ en lutumgehalte en organische stofgehalte verder niet meegenomen in de analyse.

Per model variëren de regressie- en correlatiecoëfficiënten met het landgebruik. Alle modellen blijken voor alle typen landgebruik een relatief hoge correlatiecoëfficiënt $\left(R^{2}\right)$ te hebben (Tabel B1 en B2). Voor fruitteelt, boomteelt en sportveld-/golfterrein is het aantal monsters relatief klein ten opzichte van het aantal monsters voor grasland en bouwland. De verschillen in aantallen monsters beïnvloedt de uitkomst en betrouwbaarheid van de modellen. Regressiecoëfficiënten hebben een heel kleine standaardafwijking (variatiecoëfficiënt varieert van 0,1 tot 2,3\%) De intercepten van de regressielijnen blijken in meerdere cases (typen landgebruik) significant te verschillen van 0 (nul). Dit is waarschijnlijk mede veroorzaakt door de scheve verdelingen, die per landgebruik nogal kunnen verschillen, mede door het verschil in aantal monsters (niet getoond). 
Bouwland (en groenteteelt in de volle grond) en grasland zijn verreweg de belangrijkste vormen van landgebruik. Voor de log-getransformeerde data blijken de coëfficiënten en standaardafwijkingen van de coëfficiënten van de regressiemodellen weinig te verschillen tussen bouwland en grasland. De variatiecoëfficiënten van de regressiecoëfficiënten voor de relatie tussen PPAE en het Pw-getal zijn klein $(\leq 1 \%)$ voor zowel bouwland als grasland (Tabel B1). Dat geldt ook voor de resultaten van het log-getransformeerde en exponentiële model in Tabel B2.

\section{Tabel B1}

Coëfficiënten en standaardafwijkingen van de lineaire en log-transformeerde modellen voor de relaties tussen P-AL en PW en P-PAE en PW per landgebruik.

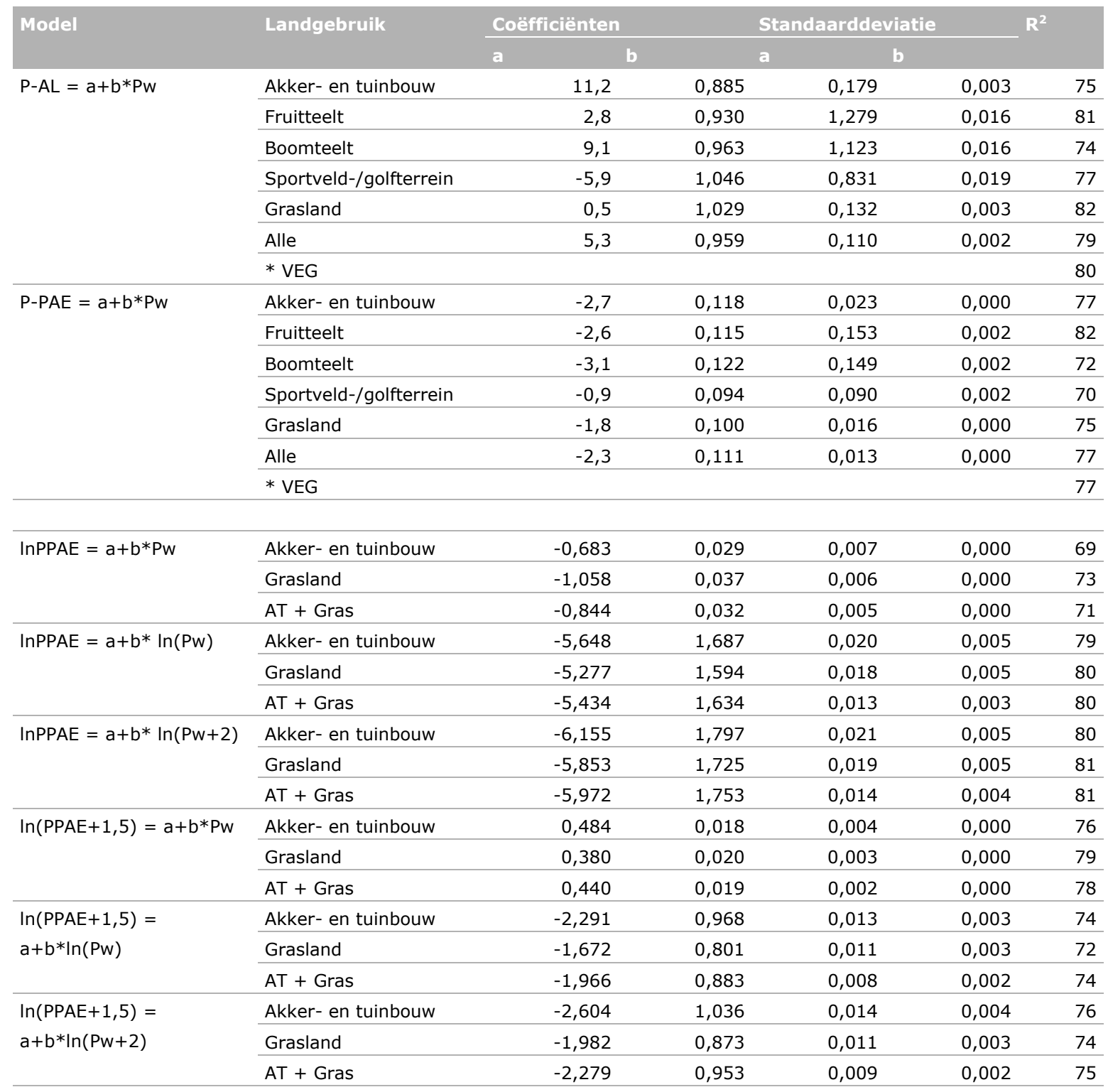

\section{Tabel B2}

Coëfficiënten en standaardafwijkingen van het exponentieel en log-getransformeerd model voor de relatie tussen P-PAE en PW per landgebruik.

\begin{tabular}{|c|c|c|c|c|c|c|c|c|}
\hline \multirow[t]{2}{*}{ Model } & \multirow[t]{2}{*}{ Landgebruik } & \multicolumn{3}{|c|}{ Coëfficiënten } & \multicolumn{3}{|c|}{ Standaarddeviatie } & \multirow[t]{2}{*}{$R^{2}$} \\
\hline & & a & b & D & a & b & D & \\
\hline \multirow[t]{3}{*}{$\operatorname{InPPAE}=a+b * D^{\wedge} P w$} & Akker- en tuinbouw & 3,00 & $-5,35$ & 0,98 & 0,019 & 0,016 & 0,000 & 81 \\
\hline & Grasland & 2,88 & $-5,16$ & 0,98 & 0,024 & 0,017 & 0,000 & 82 \\
\hline & AT + Gras & 2,97 & $-5,24$ & 0,98 & 0,015 & 0,011 & 0,000 & 82 \\
\hline
\end{tabular}




\section{Bijlage 2 Arealen per landgebruikstype en per P-klasse bestand RVO2015}

Arealen per landgebruikstype en per P-klasse uit het bestand RVO2015.

\begin{tabular}{|c|c|c|c|}
\hline Landgebruik & Landgebruiksdoel & Klasse & Areaal (ha) \\
\hline \multirow[t]{7}{*}{ Bouwland } & Agrarisch & arm & 5070 \\
\hline & & fixerend & 43387 \\
\hline & & hoog & 29468 \\
\hline & & laag & 93075 \\
\hline & & neutraal & 180194 \\
\hline & & niet opgegeven & 470588 \\
\hline & & Totaal & 821783 \\
\hline \multirow[t]{14}{*}{ Grasland } & Natuurlijk grasland & arm & 67 \\
\hline & & fixerend & 211 \\
\hline & & hoog & 198 \\
\hline & & laag & 299 \\
\hline & & neutraal & 690 \\
\hline & & niet opgegeven & 48105 \\
\hline & & Totaal & 49570 \\
\hline & Agrarisch & arm & 7300 \\
\hline & & fixerend & 38892 \\
\hline & & hoog & 109551 \\
\hline & & laag & 111023 \\
\hline & & neutraal & 303365 \\
\hline & & niet opgegeven & 367318 \\
\hline & & Totaal & 937450 \\
\hline \multirow[t]{6}{*}{ Overig } & Natuurlijk grasland & Niet opgegeven & 16441 \\
\hline & & Fixerend & 14 \\
\hline & & Totaal & 16455 \\
\hline & Overig & Niet opgegeven & 48062 \\
\hline & & Fix & 21 \\
\hline & & Totaal & 48083 \\
\hline
\end{tabular}


Alterra Wageningen UR

\section{Postbus 47}

6700 AA Wageningen

T 0317480700

www.wageningenUR.nl/alterra

Alterra-rapport 2743

ISSN 1566-7197
Alterra Wageningen UR is hét kennisinstituut voor de groene leefomgeving en bundelt een grote hoeveelheid expertise op het gebied van de groene ruimte en het duurzaam maatschappelijk gebruik ervan: kennis van water, natuur, bos, milieu, bodem, landschap, klimaat, landgebruik, recreatie etc.

De missie van Wageningen UR (University \& Research centre) is 'To explore the potential of nature to improve the quality of life'. Binnen Wageningen UR bundelen 9 gespecialiseerde onderzoeksinstituten van stichting DLO en Wageningen University hun krachten om bij te dragen aan de oplossing van belangrijke vragen in het domein van gezonde voeding en leefomgeving. Met ongeveer 30 vestigingen, 6.000 medewerkers en 9.000 studenten behoort Wageningen UR wereldwijd tot de aansprekende kennisinstellingen binnen haar domein. De integrale benadering van de vraagstukken en de samenwerking tussen verschillende disciplines vormen het hart van de unieke Wageningen aanpak. 


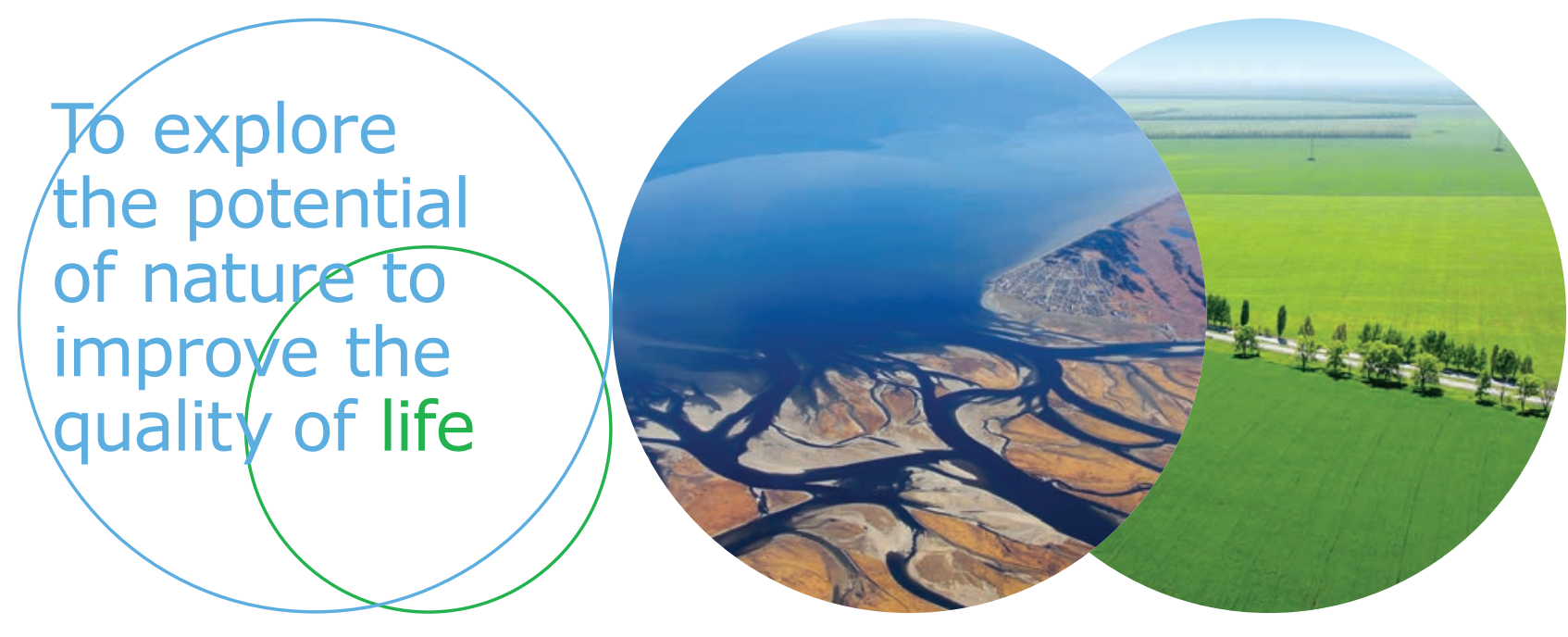

Alterra Wageningen UR

Postbus 47

6700 AA Wageningen

T 317480700

www.wageningenUR.nl/alterra

Alterra-rapport 2743

ISSN 1566-7197
Alterra Wageningen UR is hét kennisinstituut voor de groene leefomgeving en bundelt een grote hoeveelheid expertise op het gebied van de groene ruimte en het duurzaam maatschappelijk gebruik ervan: kennis van water, natuur, bos, milieu, bodem, landschap, klimaat, landgebruik, recreatie etc.

De missie van Wageningen UR (University \& Research centre) is 'To explore the potential of nature to improve the quality of life'. Binnen Wageningen UR bundelen 9 gespecialiseerde onderzoeksinstituten van stichting DLO en Wageningen University hun krachten om bij te dragen aan de oplossing van belangrijke vragen in het domein van gezonde voeding en leefomgeving. Met ongeveer 30 vestigingen, 6.000 medewerkers en 9.000 studenten behoort Wageningen UR wereldwijd tot de aansprekende kennisinstellingen binnen haar domein. De integrale benadering van de vraagstukken en de samenwerking tussen verschillende disciplines vormen het hart van de unieke Wageningen aanpak. 